\title{
Effect of Roof Tile Colour on Heat Conduction Transfer, Roof-Top Surface Temperature and Cooling Load in Modern Residential Buildings under the Tropical Climate of Malaysia
}

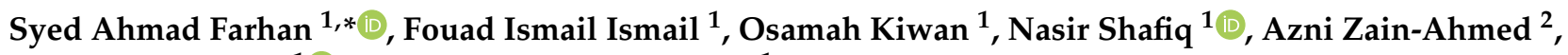 \\ Nadzhratul Husna ${ }^{1}$ (D) and Afif Izwan Abd Hamid ${ }^{1}$ \\ 1 Institute of Self-Sustainable Building, Universiti Teknologi PETRONAS, Seri Iskandar 32610, Malaysia; \\ fouad_20001008@utp.edu.my (F.I.I.); osamah_g03699@utp.edu.my (O.K.); nasirshafiq@utp.edu.my (N.S.); \\ nadzrahusnaz@gmail.com (N.H.); afif_g03455@utp.edu.my (A.I.A.H.) \\ 2 Office of International Affairs, Universiti Teknologi MARA, Shah Alam 40450, Malaysia; \\ azniz132@uitm.edu.my \\ * Correspondence: syfarisk@gmail.com
}

\section{check for} updates

Citation: Farhan, S.A.; Ismail, F.I.; Kiwan, O.; Shafiq, N.; Zain-Ahmed, A.; Husna, N.; Hamid, A.I.A. Effect of Roof Tile Colour on Heat Conduction Transfer, Roof-Top Surface

Temperature and Cooling Load in Modern Residential Buildings under the Tropical Climate of Malaysia. Sustainability 2021, 13, 4665

https://doi.org/10.3390/su13094665

Academic Editor: Asterios Bakolas

Received: 23 February 2021

Accepted: 10 April 2021

Published: 22 April 2021

Publisher's Note: MDPI stays neutral with regard to jurisdictional claims in published maps and institutional affiliations.

Copyright: (c) 2021 by the authors. Licensee MDPI, Basel, Switzerland. This article is an open access article distributed under the terms and conditions of the Creative Commons Attribution (CC BY) license (https:/ / creativecommons.org/licenses/by/ $4.0 /)$.

\begin{abstract}
Modern residential roofs in Malaysia mainly employ red and brown roof tiles due to aesthetic factors and the ability of the roof surface to reflect or retard heat transfer is typically not considered the main priority. The present article reveals the findings of a study on the effect of roof tile colour on heat conduction transfer through roof tiles and ceiling boards, roof-top surface temperature and cooling load. Findings suggest that the selection of white roof tiles significantly reduces the peaks of heat conduction transfer and roof-top surface temperature as well as the values of heat conduction transfer and roof-top surface temperature throughout diurnal profiles, which consequently reduces hours of indoor thermal discomfort and use of air-conditioners in indoor spaces. A decline in peak roof-top surface temperature of up to $16.00{ }^{\circ} \mathrm{C}$ that results in annual energy savings of up to $13.14 \%$ can be achieved when the roof tile colour is changed from red to white. Further research on the development of solar-reflective paint or coating products that can significantly increase the solar reflectance values of non-white roof tiles are essential to overcome issues related to maintenance difficulties and lack of preference among house buyers towards white roof tiles.
\end{abstract}

Keywords: air-conditioner; cooling load; heat conduction; residential building; roof tile colour; roof-top surface; solar reflectance; temperature; thermal comfort; tropical climate

\section{Introduction}

Solar radiation in Malaysia is intense for long periods throughout the year [1] as the position of Malaysia is within the equatorial region [2] and hence, it has a tropical climate, which elevates the use of air-conditioners in indoor spaces among occupants [3] to fulfil the requirements of indoor thermal comfort. Reports on the Population and Housing Census of Malaysia for 2000 and 2010 [4,5] reveal that the ownership of air-conditioners has increased from 777,600 to 1,416,050 units during the period from 2000 to 2010. Findings of a survey conducted by Al Yacouby et al. [6] on potential house buyers from the urban cities of Ipoh, Johor Bahru, Kuala Lumpur, Petaling Jaya and Shah Alam suggest that 74.5\% of the respondents employ an average of three air-conditioner units per household with average operation periods of five hours per unit each day [6]. In another survey conducted by Kubota et al. [7] on households in the urban area of Johor Bahru that reside in typical modern residential buildings of Malaysia, results reveal that the rate of ownership of air-conditioners among the households is $65 \%$, with, on average per household, operation periods of six hours per day and projected energy consumption of $1167 \mathrm{kWh}$ per year. The air-conditioner is the largest contributor to energy consumption among all of the common 
household appliances that include, among others, ceiling fans, refrigerators, fluorescent lamps, water heaters, televisions and rice cookers [7]. The increased dependence on airconditioners is a concern as air-conditioners heavily consume energy [8], which leads to elevated levels of carbon emission contributed by the residential sector of Malaysia.

According to Al-Obaidi et al. [9], surfaces in urban cities that are exposed to solar radiation are primarily roof-top surfaces. For residential buildings, which are predominantly low-rise, the intense and prolonged solar radiation heats up the roof assembly more than any other building envelope component as the roof-top surface has the highest exposure to solar radiation [8]. Heat gain through residential roofs is primarily in the form of radiation [10] and accounts for about $50 \%$ to $70 \%$ of the total heat gain into the indoor spaces below the ceiling board [11].

Modern residential buildings in Malaysia commonly adopt pitched roofs, which protect the buildings from intense solar radiation as well as rainwater [9]. The roof pitch generates the gravitational force required to drain off the water [12]. Typically, concrete is adopted as the roof tile material due to the low cost and high resistance to solar radiation and rainwater and not due to thermal properties [9]. The assembly of the pitched roof is presented in Figure 1.

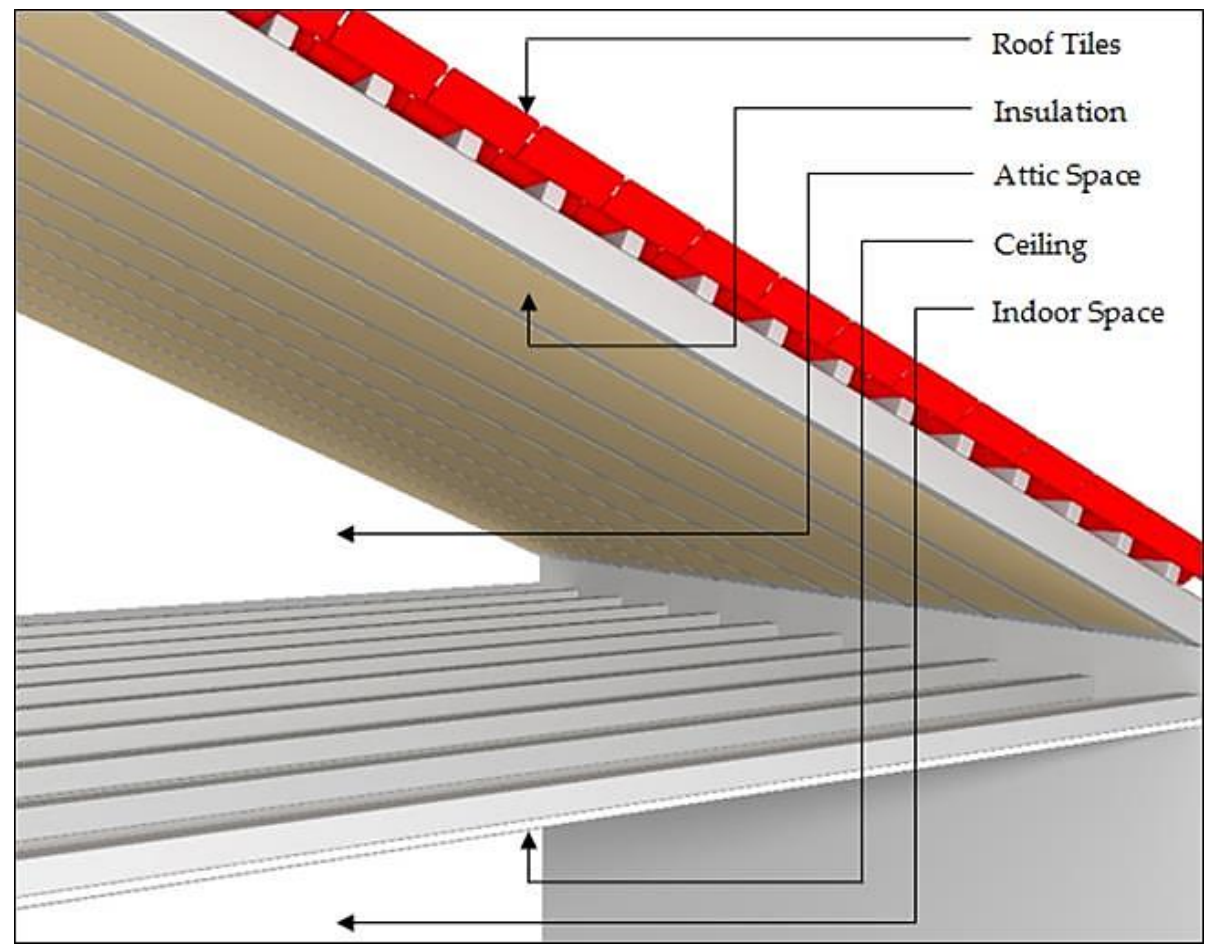

Figure 1. Assembly of the pitched roof.

Based on findings of the survey by Al Yacouby et al. [6], existing modern residential roofs in Malaysia mainly employ red and brown roof tiles. The survey also studied colour preferences among potential house buyers of Malaysia, which are also found to be primarily red and brown. The preference among house owners towards brown colours for pitched roofs is also present in Thailand, as highlighted by Thongkanluang et al. [13]. The selection of red and brown as surface colours for the majority of residential roofs in Malaysia is based on aesthetic factors as the ability of the roof-top surface to reflect or retard heat transfer is typically not considered the main priority. Hence, research is essential to shed light on the effect of roof tile colour on heat transfer in modern residential buildings under the climate of Malaysia.

Al Yacouby et al. [6] and Al-Obaidi et al. [9] highlighted that the application of cool colours for roofs in tropical countries inclusive of Malaysia is low even though it 
is widely recognized and has been proven to be able to significantly reduce the cooling load for various climate classes as demonstrated in Synnefa et al. [14]. In the region of Southeast Asia, research related to the colour of roof-top surfaces is scarce and limited to Al Yacouby et al. [6] and Al-Obaidi et al. [9] in Malaysia, Thongkanluang et al. [13] in Thailand, Zingre et al. [15] in Singapore and Syuhada and Maulana [16] in Indonesia. Recent research related to the heat transfer in modern residential buildings under the climate of Malaysia focused on the micro-climate that the building is subjected to [17] and the installation of insulation materials in the roof assembly [18-21] and did not consider the application of cool colours on roof-top surfaces.

Al Yacouby et al. [6] compared indoor temperatures of two variations of a test cell in Perak, Malaysia with dimensions of $3 \mathrm{~m}$ length by $3 \mathrm{~m}$ width by $2.5 \mathrm{~m}$ height that adopt black and white roof surfaces. Findings indicated that the white roof reflected around $700 \%$ more sunlight than the black roof and reduced the peak indoor temperature by up to $1.7^{\circ} \mathrm{C}$ relative to the black roof.

Al-Obaidi et al. [9] compared the impacts of roof surface colour, area, material and pitch of a Building Information Model (BIM) with dimensions of $5.0 \mathrm{~m}$ length by $4.0 \mathrm{~m}$ width by 3.0 m height. The BIM was positioned in Penang, Malaysia and adopted black, red and white roof surfaces. Findings highlighted that the roof surface colour has a more significant impact on heat gain than roof area, material and pitch. Syuhada and Maulana [16] evaluated the thermal performances of corrugated steel zinc roofs of black, blue, brown, chrome, green, grey, maroon, orange, red and white colours using an experimental chamber that was made out of transparent plastic and wood with dimensions of $1.3 \mathrm{~m}$ length by $1.3 \mathrm{~m}$ width by $1.8 \mathrm{~m}$ height. Findings substantiated that the zinc roof with darker colours absorbs significantly higher amounts of heat in comparison to the lighter colours. Thongkanluang et al. [13] synthesized brown pigments that possess a high near-infrared solar reflectance for the application as ceramic roof coating due to their high reflectance and durability. Zingre et al. [15] developed a cool roof heat transfer model, which was then validated against experiments that were performed on flat roofs of apartments in Singapore. Findings revealed that the application of a white coating on the flat roof can reduce the peak indoor air temperature by up to $2.4^{\circ} \mathrm{C}$.

Research by Al Yacouby et al. [6] and Al-Obaidi et al. [9] for the climate of Malaysia is limited to the adoption of black, red and white roof tiles and does not include other colours that are commonly adopted in Malaysia for concrete roof tile surfaces such as brown, gold, grey and orange, based on the findings of Al Yacouby et al. [6], as well as data provided by several local manufacturers. Even though the majority of the colours mentioned are included in the research by Syuhada and Maulana [16], which adopted black, blue, brown, chrome, green, grey, maroon, orange, red and white colours for the roof surface, but the research is focused on zinc roofs, which is generally applicable for buildings in Indonesia but is not the most common roof tile material adopted in modern residential buildings of Malaysia. Moreover, the experimental chamber employed in Syuhada and Maulana [16] was not constructed using the conventional materials of modern residential buildings in Malaysia as it was constructed from transparent plastic and wood. Furthermore, the test cells employed in Al Yacouby et al. [6] and Al-Obaidi et al. [9] do not conform to the minimum requirements for habitable rooms of a residential building in Malaysia as stated in UBBL 1984 [22]. The test cells employed in Al Yacouby et al. [6] do not fulfil the requirements stated in Clauses 42 (1), 42 (2) and 44 (1) of UBBL 1984 [22] as the base areas are below $11 \mathrm{~m}^{2}$. On the other hand, the BIM employed in Al-Obaidi et al. [9] does not comply with Clause 39 (1) of UBBL 1984 [22] as the building envelope is designed without a window.

The experiment conducted in Zingre et al. [15] focuses on flat roofs, which do not represent the majority of modern residential roofs in Malaysia that adopt pitched roof assemblies with attic spaces and ceiling boards. The research performed in Thongkanluang et al. [13] focuses on the synthesis of the roof coating material and hence does not report its effect on the heat transfer in residential buildings that are subjected to solar radiation. 
The present article reveals findings of a study on the effect of concrete roof tile colour, which includes all the colours that are commonly adopted in Malaysia for concrete roof tiles, which are brown, gold, grey, orange and red, as well as black and white as the reference colours, on heat conduction transfer through roof tiles and ceiling boards and roof-top surface temperature as well as annual cooling load and energy savings. The impact of colour on the solar reflectance and infrared emittance values of the roof tile surface is also studied.

Malaysia is selected as the location of study as it is subjected to the tropical climate and is within the region of Southeast Asia, which is the focus of the study, as the application of cool colours for roofs of modern residential buildings in tropical countries at present is low and research related to the colour of roof surfaces in the region of Southeast Asia is scarce, even though its impact on the reduction of cooling load for other climate classes has been proven. Notwithstanding the limitation of the study, which collects data solely based on the climate of Malaysia, findings of the study are pertinent to countries other than Malaysia that are subjected to the tropical climate, especially the neighbouring countries located in Southeast Asia, such as Brunei Darussalam, Indonesia, Singapore and the southern region of Thailand.

\section{Methodology}

The methodology employed in the present study comprises laboratory measurements of solar reflectance and infrared emittance of roof tile samples, collection of heat conduction transfer and temperature simulation data of baseline and modified BIMs in Integrated Environmental Solutions <Virtual Environment $>(\mathrm{IES}<\mathrm{VE}>)$ ) and validation of the simulation data by performing a field experiment on two test cells in Shah Alam at Global Positioning System coordinates of $3.07^{\circ} \mathrm{N}, 101.50^{\circ} \mathrm{E}$.

Solar reflectance is a measure of the ability of a material to reflect incident solar radiation without absorbing it [23]. Infrared emittance measures the capability of the surface to re-emit the previously absorbed heat away from itself [24]. Their values are expressed as ratios that range from 0 to 1 without units. Solar reflectance and infrared emittance of roof tile surfaces as shown in Figure 2 were measured using instruments manufactured by the Devices and Services Company, which were a solar spectrum reflectometer of Model SSR-ER as shown in Figure 3 and an emissometer of Model AE1 that was equipped with a scaling digital voltmeter of Model RD1 as shown in Figure 4.

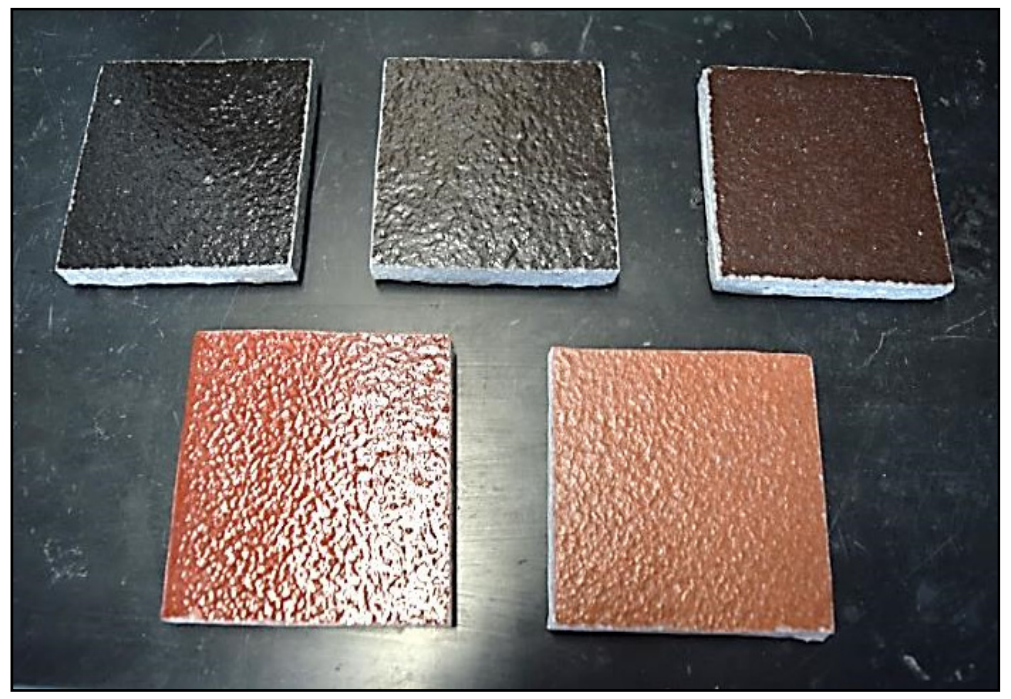

Figure 2. Roof tile samples. 


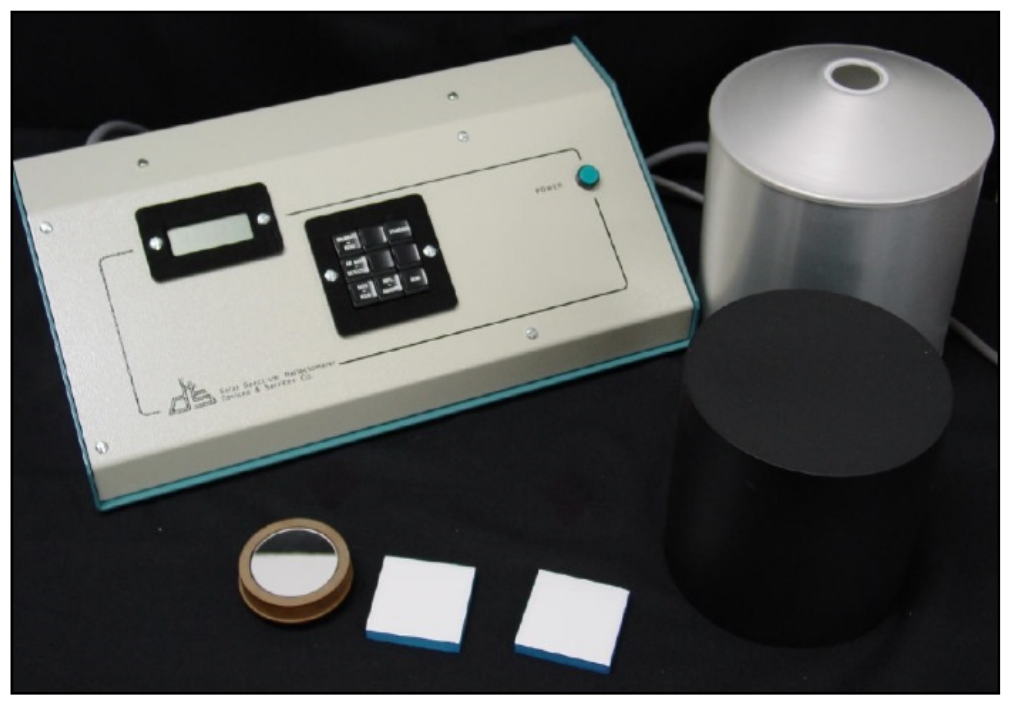

Figure 3. Solar spectrum reflectometer.

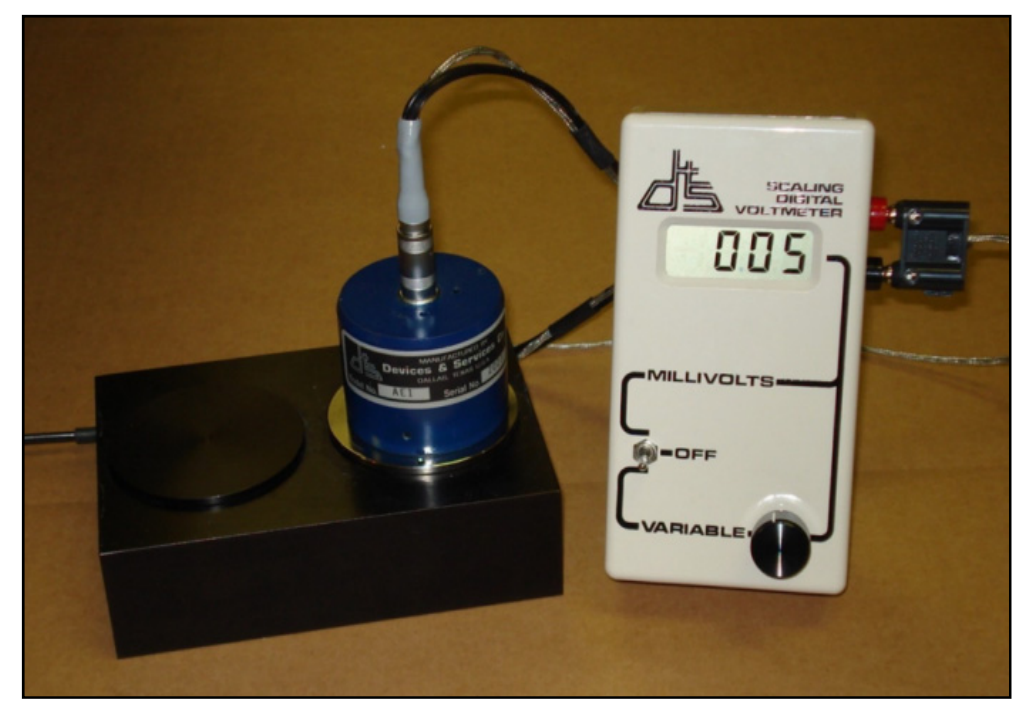

Figure 4. Emissometer with scaling digital voltmeter.

Two bodies that are not in contact with one another can emit electromagnetic waves that travel through air or vacuum spaces, which causes radiation heat transfer to occur between the surfaces of the bodies [25]. The rate of the heat transfer can be calculated using Equations (1) and (2) [26].

$$
\begin{gathered}
Q_{\text {radiation }}=\sigma A_{1} \varepsilon_{1}\left(T_{1}^{4}-T_{2}{ }^{4}\right) \\
Q_{\text {radiation }}=h_{r} A_{1}\left(T_{1}-T_{2}\right)
\end{gathered}
$$

where $\sigma$ is the Stefan $\neg-$ Boltzmann constant, $A_{1}$ and $\varepsilon_{1}$ are the area and emissivity of the first surface, $T_{1}$ and $T_{2}$ are the absolute temperatures of the first and second surfaces and $h_{r}$ is the coefficient of heat transfer.

Solar reflectance and infrared emittance data were analysed and then employed to create a BIM in IES $<$ VE $>$ as shown in Figure 5 for the analysis of heat conduction transfer through roof tiles and ceiling boards, roof-top surface temperature and cooling load. 

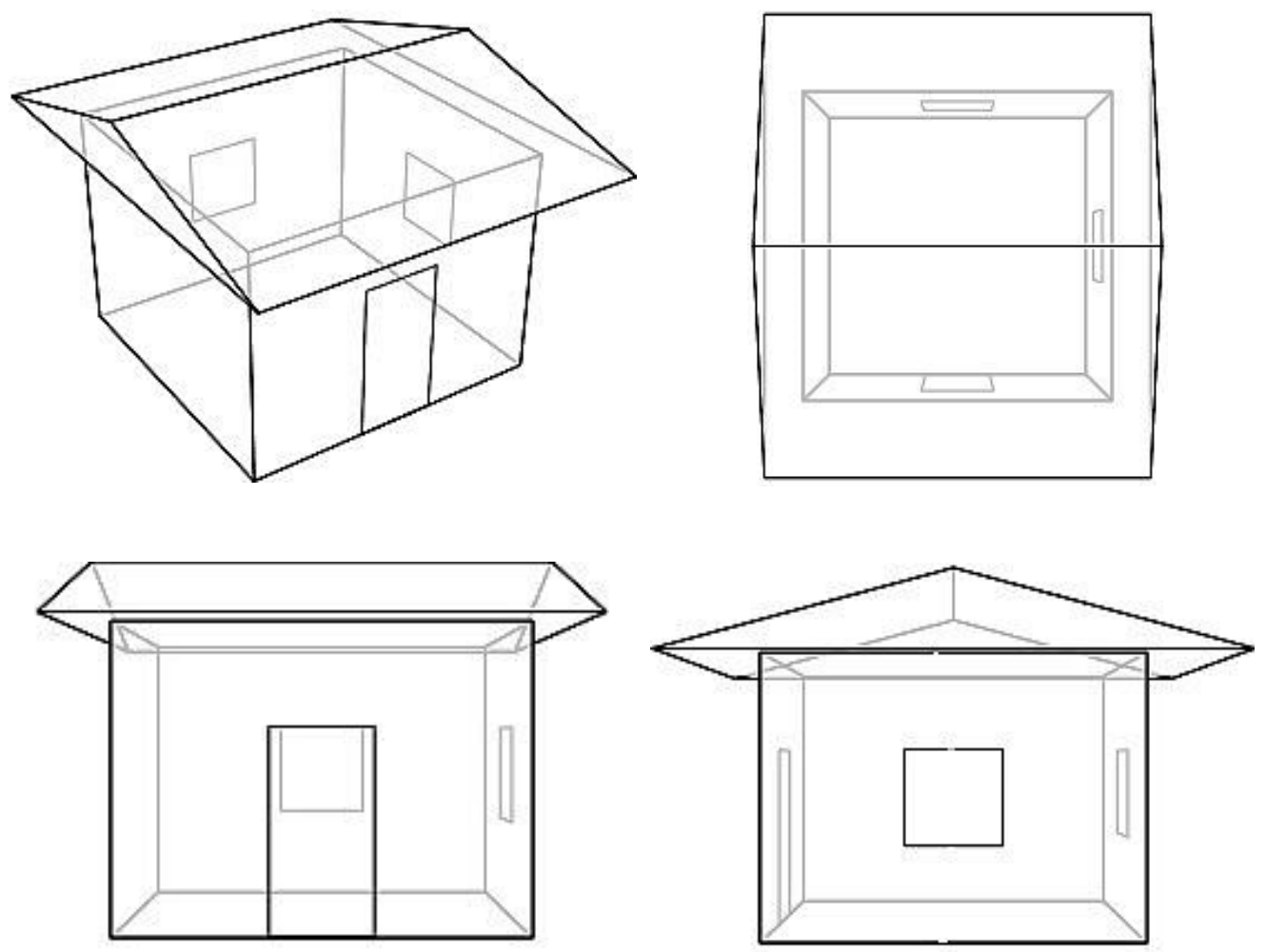

Figure 5. BIM created in IES $<$ VE $>$.

Conduction heat transfer happens through a solid material when a difference in temperature is present across the material. Heat is transferred from atoms that possess higher kinetic energy to atoms with lower kinetic energy as a result of the vibration of adjacent atoms that are in contact with one another [25]. According to Fourier's Law, the rate of heat transfer is proportional to the temperature gradient and cross-sectional area that is perpendicular to the gradient through which the heat flow occurs as presented in Equation (3) [27].

$$
Q_{\text {conduction }}=k A \frac{d T}{d x}
$$

where $k$ is the thermal conductivity of the material expressed in $\mathrm{W} / \mathrm{mK}, A$ is the crosssectional area perpendicular to heat flow expressed in $\mathrm{m}^{2}$ and $d T / d x$ is the temperature gradient expressed in $\mathrm{K} / \mathrm{m}$.

Two identical test cells were constructed within the campus of Universiti Teknologi MARA in Shah Alam at $3.07^{\circ} \mathrm{N}, 101.50^{\circ} \mathrm{E}$ as shown in Figure 6 to replicate the BIM for the validation of simulation data in IES $<\mathrm{VE}>$. The design of the BIM and test cells represents typical rooms of modern residential buildings in urban areas of Malaysia. Their dimensions of $4 \mathrm{~m}$ length by $4 \mathrm{~m}$ width by $3 \mathrm{~m}$ height fulfilled the minimum size requirements for a habitable room in a residential building as stated in Clauses 42 (1), 42 (2) and 44 (1) of UBBL 1984 [22], which state that the base area, width and height must not be less than $11 \mathrm{~m}^{2}, 2 \mathrm{~m}$ and $2.5 \mathrm{~m}$, respectively.

Two identical windows were installed on the north and west walls with dimensions of $1.075 \mathrm{~m}$ height and $0.950 \mathrm{~m}$ width. The windows were constructed from 6-mm thick clear float glass with an aluminium frame. The external view of the north wall window is shown in Figure 7. The total opening area was equivalent to a window-to-wall-ratio of 0.04 and $12.76 \%$ of the floor area, which complies with Clause 39 (1) of UBBL 1984 [22] that states that the total area of windows of a habitable room in a residential building must not be less than $10 \%$ of the floor area of the room. 


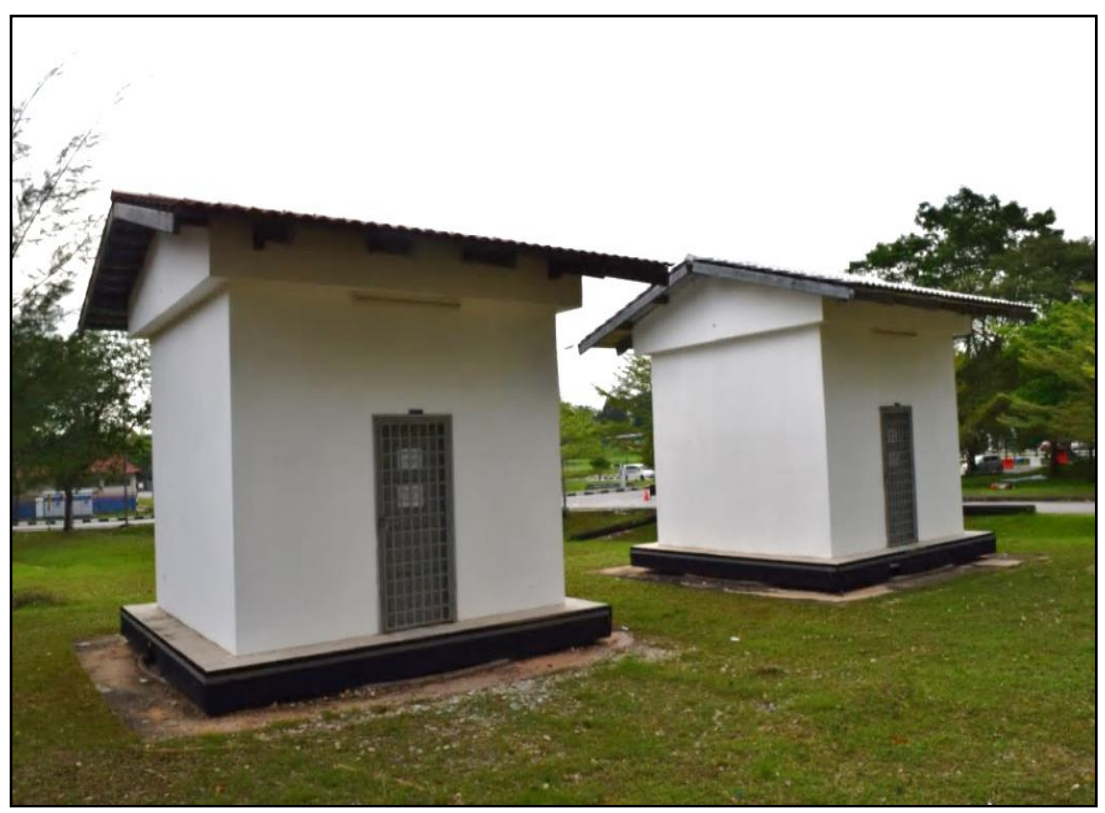

Figure 6. Test cells.

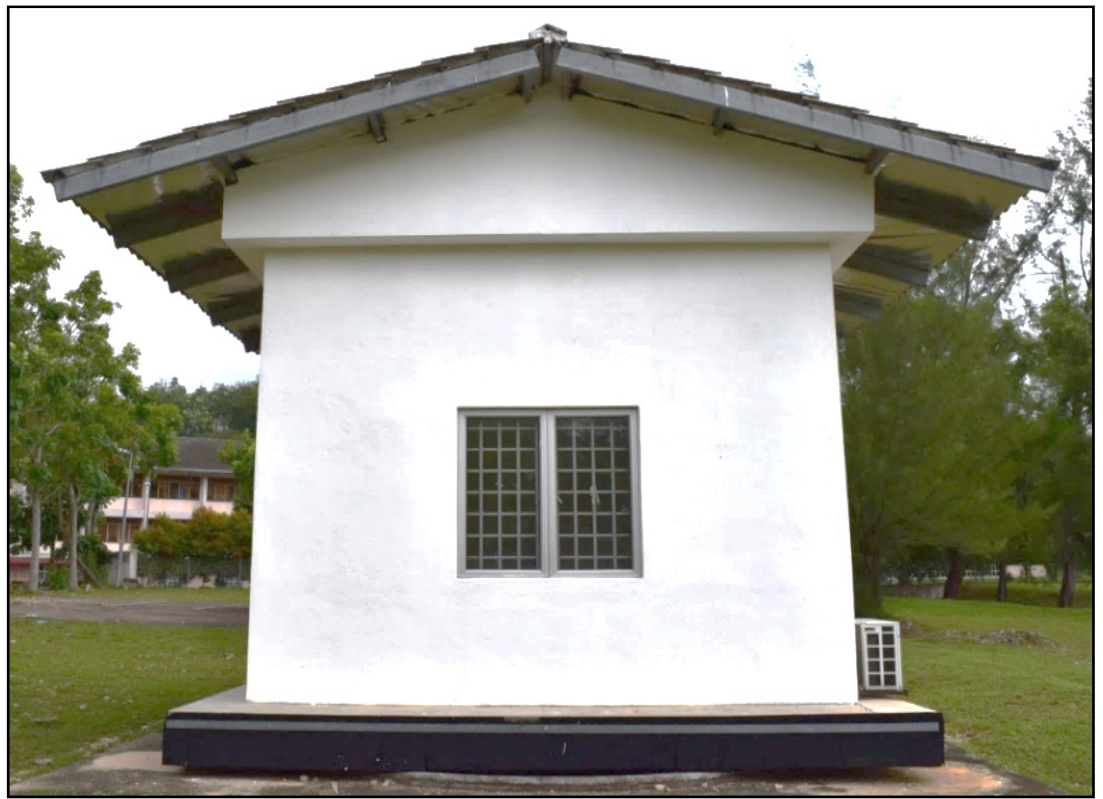

Figure 7. External view of the north wall window.

The density, specific heat, $k$-value and thickness of the materials employed to construct the test cells are presented in Table 1 . The materials were determined based on the designs of typical modern residential buildings in Malaysia as employed in the research of Irwan et al. [28,29], Halim et al. [30], Morris et al. [31,32] and Zakaria et al. [33].

A lightweight roof assembly that comprised $10-\mathrm{mm}$ thick cement roof tiles that were laid on a $15^{\circ}$-pitched steel roof structure and a $4.5-\mathrm{mm}$ thick cement ceiling board below an attic space was employed to represent the typical residential roof assembly of the majority of households in urban areas of Malaysia, which inhabit terraced residential buildings, as highlighted in Al Yacouby et al. [6] and the Characteristics of Living Quarters 2010 report [34]. Furthermore, terraced residential buildings are also exposed to the highest rate of heat transfer through the roof due to their low height in comparison to other building types. The roof surface of the test cells had maximum exposure to solar radiation as their 
pitch was aligned with the West-East axis. The roof tiles of Test Cell A (TCA) and Test Cell B (TCB) were painted red and white, respectively, as shown in Figures 8 and 9.

Table 1. Properties of the materials employed to construct the test cells.

\begin{tabular}{|c|c|c|c|c|c|}
\hline Construction & Material & $\begin{array}{l}\text { Density } \\
\left(\mathrm{kg} / \mathrm{m}^{3}\right)\end{array}$ & $\begin{array}{c}\text { Specific Heat } \\
(\mathrm{J} / \mathrm{kgK})\end{array}$ & $\begin{array}{l}k \text {-Value } \\
(\mathrm{W} / \mathrm{mK})\end{array}$ & $\begin{array}{c}\text { Thickness } \\
\text { (mm) }\end{array}$ \\
\hline Roof & Concrete Tile & 1890 & 1000 & 0.836 & 10.0 \\
\hline Ceiling & Cement Board & 720 & 1000 & 0.250 & 4.5 \\
\hline Window & Clear Float Glass & 2800 & 800 & 0.810 & 6.0 \\
\hline Door & Solid Timber & 702 & 2720 & 0.138 & 38.0 \\
\hline \multirow{3}{*}{ Wall } & Cement Plaster & 1690 & 840 & 0.533 & 18.0 \\
\hline & Clay Brick & 1800 & 800 & 1.154 & 114.0 \\
\hline & Cement Plaster & 1690 & 840 & 0.533 & 18.0 \\
\hline Floor & Reinforced Concrete & 2400 & 1000 & 1.442 & 50.0 \\
\hline
\end{tabular}

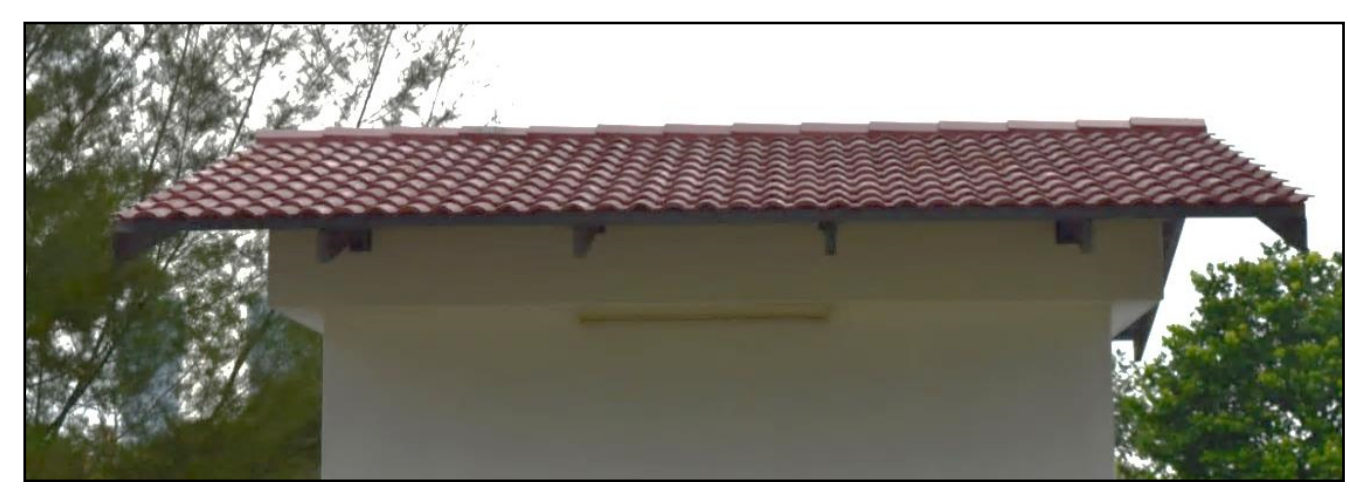

Figure 8. Red roof of Test Cell A.

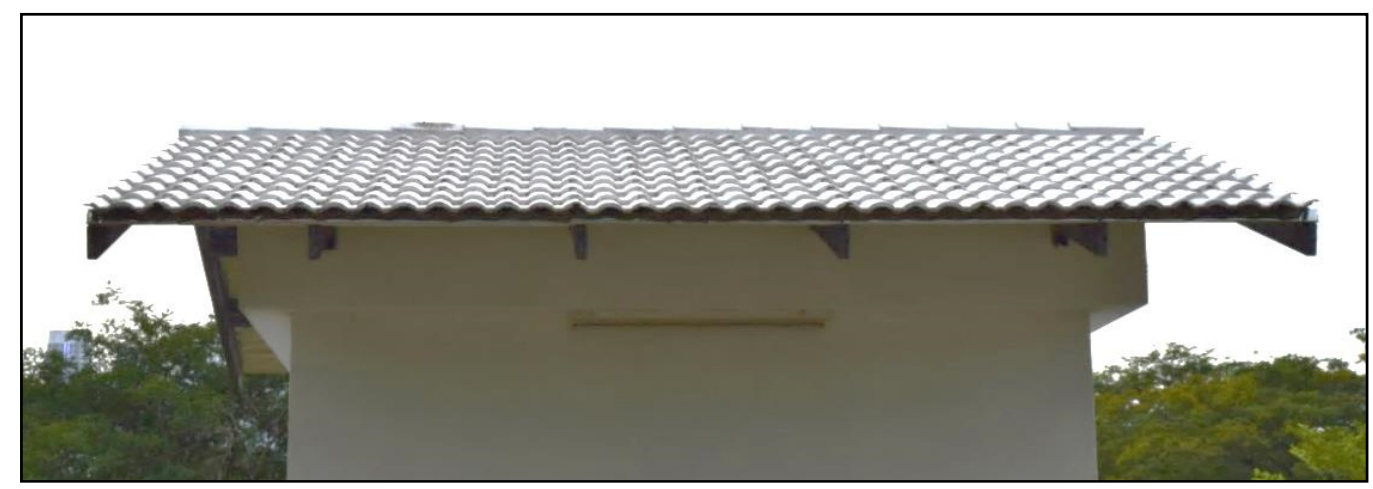

Figure 9. White roof of Test Cell B.

Each test cell was equipped with four fibreglass-insulated K-type thermocouples that were connected to one unit of a four-channel K-type temperature data logger to record hourly temperatures of the roof-top surface, attic air, ceiling-bottom surface and indoor air of both test cells simultaneously throughout the whole of 2018. The thermocouples consisted of chromel and alumel wires that were connected to the data loggers with connectors and welded at the opposite ends to create junctions where temperatures were measured. They were insulated with fibreglass braiding and could be utilized within the temperature range of $-200{ }^{\circ} \mathrm{C}$ to $1250^{\circ} \mathrm{C}$, which is wider than the temperature range required for the present research. Accordingly, the data loggers could measure temperatures within the range of $-200{ }^{\circ} \mathrm{C}$ to $1370{ }^{\circ} \mathrm{C}$, which also fulfils the requirement of the present research. They performed measurements at a resolution of $0.1^{\circ} \mathrm{C}$ with an accuracy of $\pm 1{ }^{\circ} \mathrm{C}$ and a sampling rate of $\geq 1 \mathrm{~s}$. They could be operated within the temperature range of $0{ }^{\circ} \mathrm{C}$ to 
$50{ }^{\circ} \mathrm{C}$ and at a relative humidity range of below $80 \%$. Inspections were performed before commencing the data collection to ensure that the measured data are accurate. The concept of the research is depicted as a framework as shown in Figure 10.

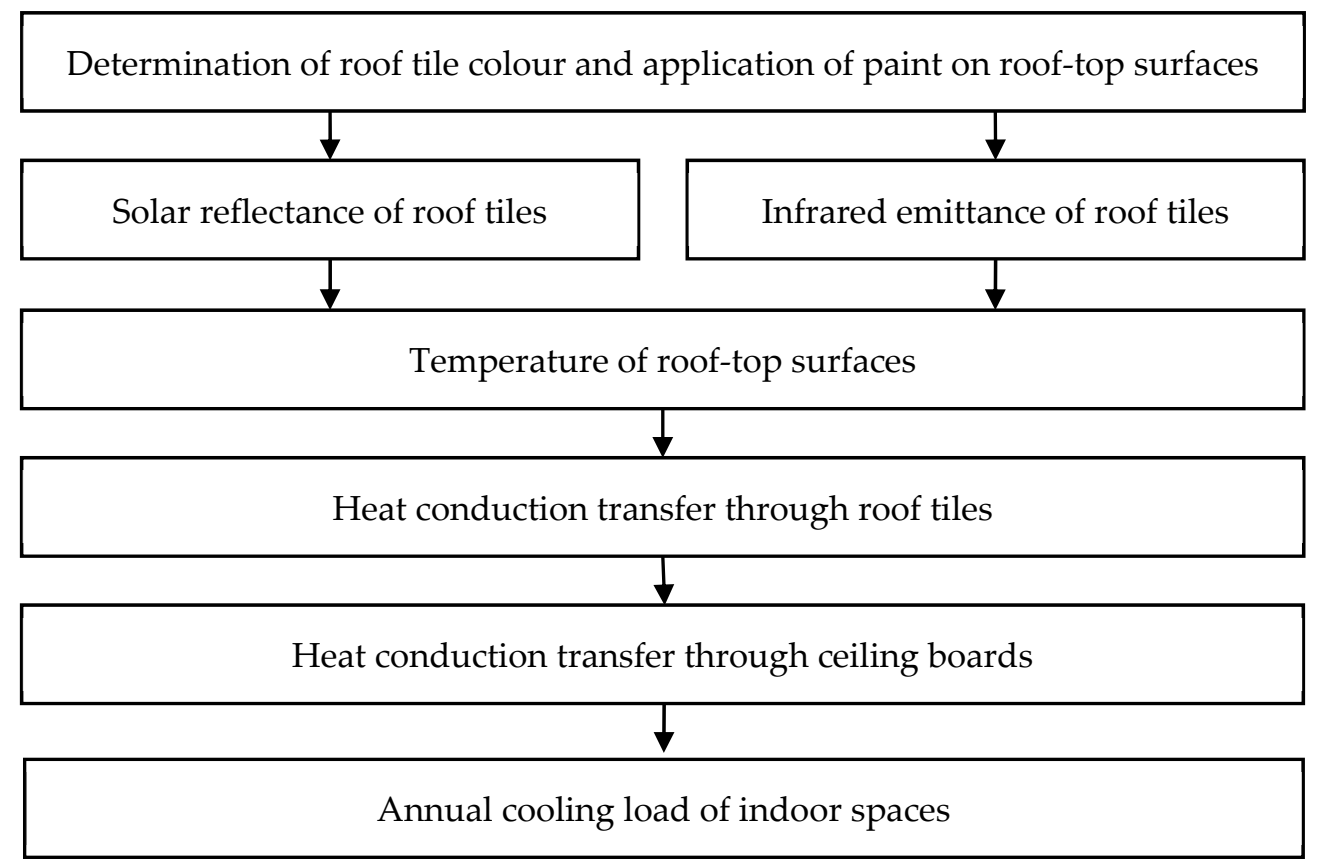

Figure 10. Conceptual framework of the research.

Absolute percentage differences, $\left|P D_{S D-F M}\right|$, between the temperature data of the test cells throughout the whole of 2018 and the BIM throughout the whole of the typical meteorological year for the site location at $3.07^{\circ} \mathrm{N}, 101.50^{\circ} \mathrm{E}$ were calculated based on Equation (4) as employed by Vangimalla et al. [29]. Simulation data of IES $<$ VE $>$ were validated if the range of $\left|P D_{S D-F M}\right|$ values was less than $20 \%$, which was determined based on the acceptable ranges adopted in similar research [35-37].

$$
P D_{S D-F M}=\frac{S D-F M}{F M} \times 100 \%
$$

where $S D$ is the simulation data, $F M$ is the data collected from field measurements and $P D_{S D-F M}$ is the percentage difference between $S D$ and $F M$.

The process flow of the methodology adopted throughout the research is presented in Figure 11. 


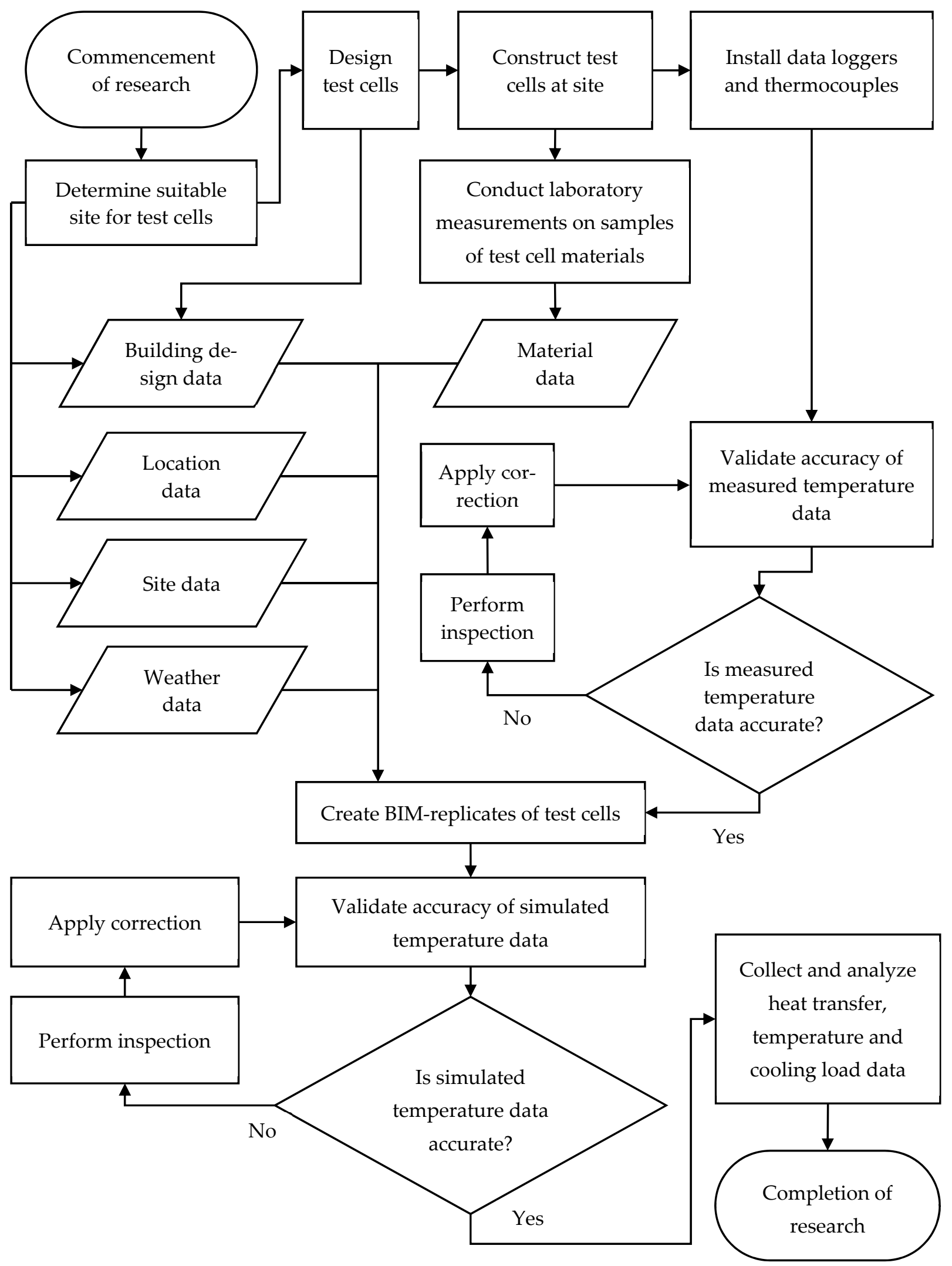

Figure 11. Process flow of research methodology. 


\section{Results}

Solar reflectance values of the roof tile samples are shown in Figure 12. Results indicate that the most typical roof tile colour adopted in Malaysia, which is red [6], has the third-highest solar reflectance value of 0.2000 , whereby the highest and lowest solar reflectance values of 0.7300 and 0.0450 are obtained for white and black roof tiles. Among the non-white and non-black roof tiles, the solar reflectance value of the orange roof tile of 0.2650 is the highest. Red and gold roof tiles possess solar reflectance values that are close to each other, which are 0.2000 and 0.1955 . Comparison between solar reflectance values of brown and grey roof tiles, which are 0.0605 and 0.0570 , also demonstrate a trivial difference. Figure 13 presents the infrared emittance values of the roof tile samples and reports that the measured values range between 0.880 and 0.915 with inconsequential differences between them.

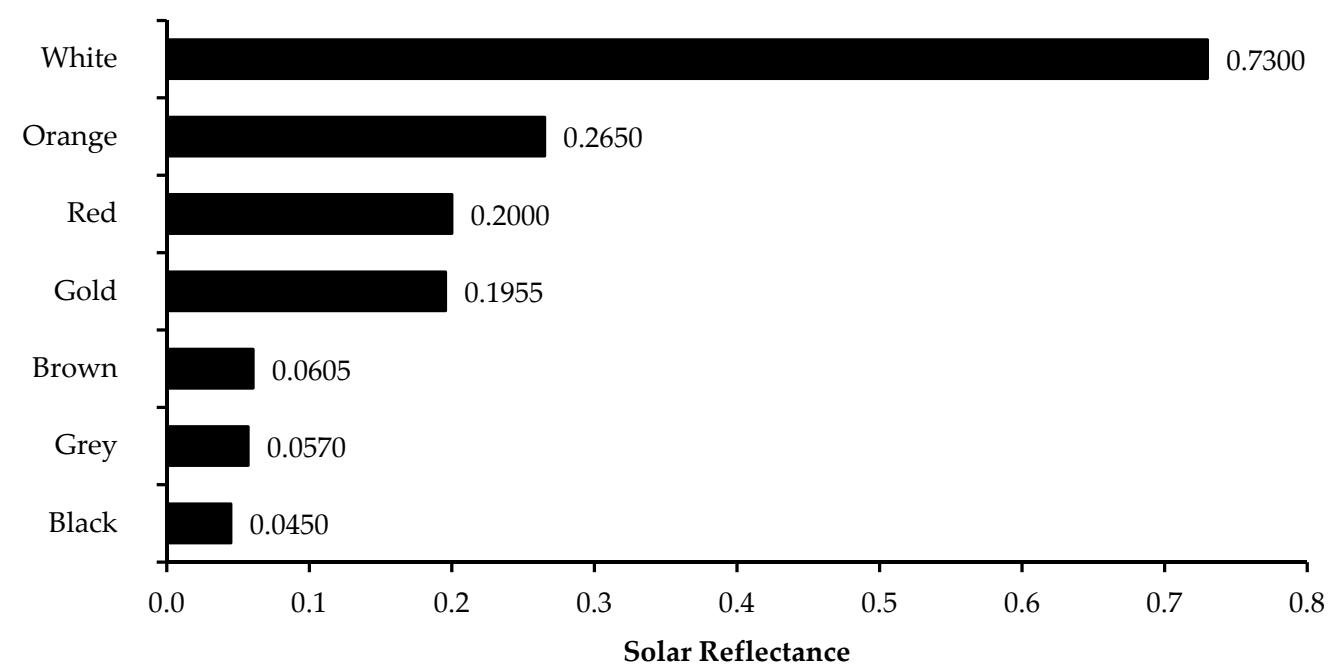

Figure 12. Solar reflectance values of roof tile samples.

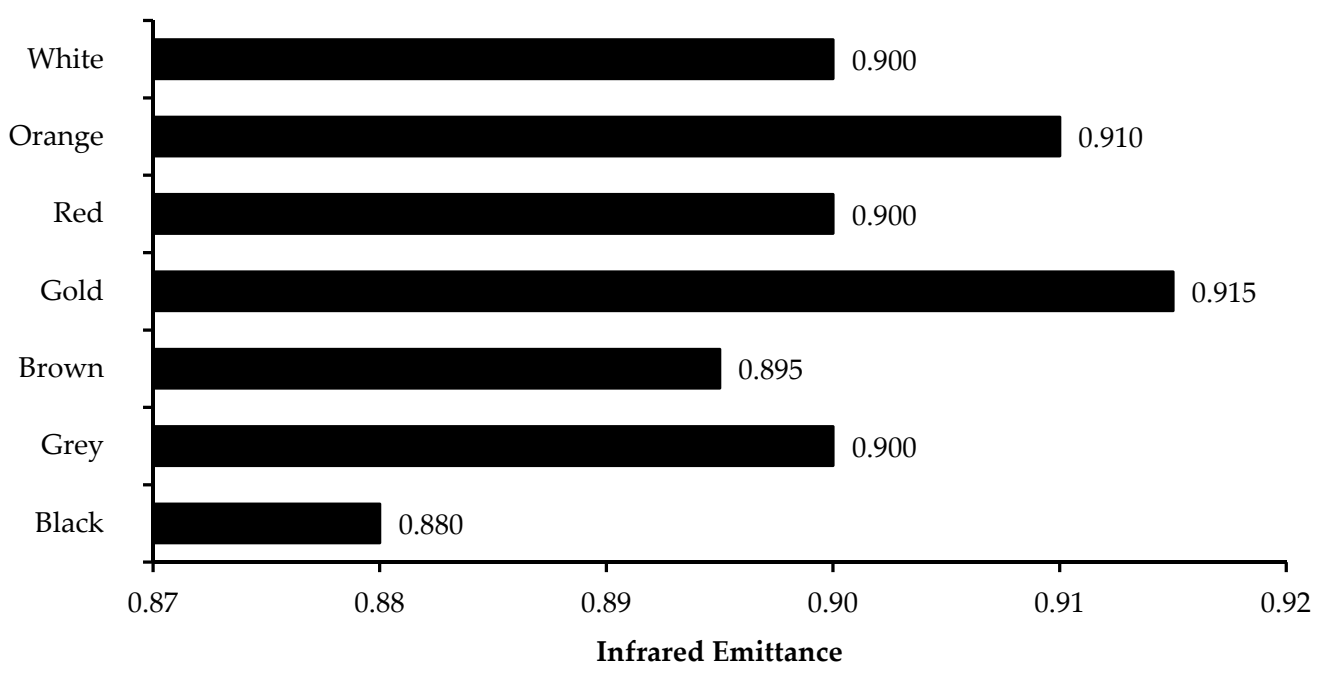

Figure 13. Infrared emittance values of roof tile samples.

The highest $\left|P D_{S D-F M}\right|$ value obtained in the present study is $9.89 \%$, which is within the acceptable range of $20 \%$. Hence, the validity of the simulation data of IES $<\mathrm{VE}>$ that were obtained from the present research is confirmed.

The BIM that adopts red roof tiles is referred to as the baseline BIM while the BIMs that adopt black, brown, orange and white roof tiles are referred to as modified BIMs. Gold and grey roof tiles are omitted from the BIM simulation as their solar reflectance values, 
which are 0.1955 and 0.0570 , are close to those of red and brown roof tiles, which are 0.2000 and 0.0605 , and hence the differences between their effects on the heat transfer through the roof to those of red and brown roof tiles can be assumed to be inappreciable.

Figure 14 presents the diurnal annual-averaged profiles of heat conduction transfer through the roof tiles, $Q_{C O N D R}$, of the baseline and modified BIMs for each roof tile colour. The profiles are generated based on hourly $Q_{C O N D R}$ data logged from 7:30 to 19:30 throughout the typical meteorological year at $3.07^{\circ} \mathrm{N}, 101.50^{\circ} \mathrm{E}$. Positive $Q_{C O N D R}$ values indicate that the heat conducts from the outdoor environment into the attic space through the roof tiles, whereas negative $Q_{C O N D R}$ values indicate that the heat transfer takes place in the opposite direction, which is from the attic space to the outdoor environment.

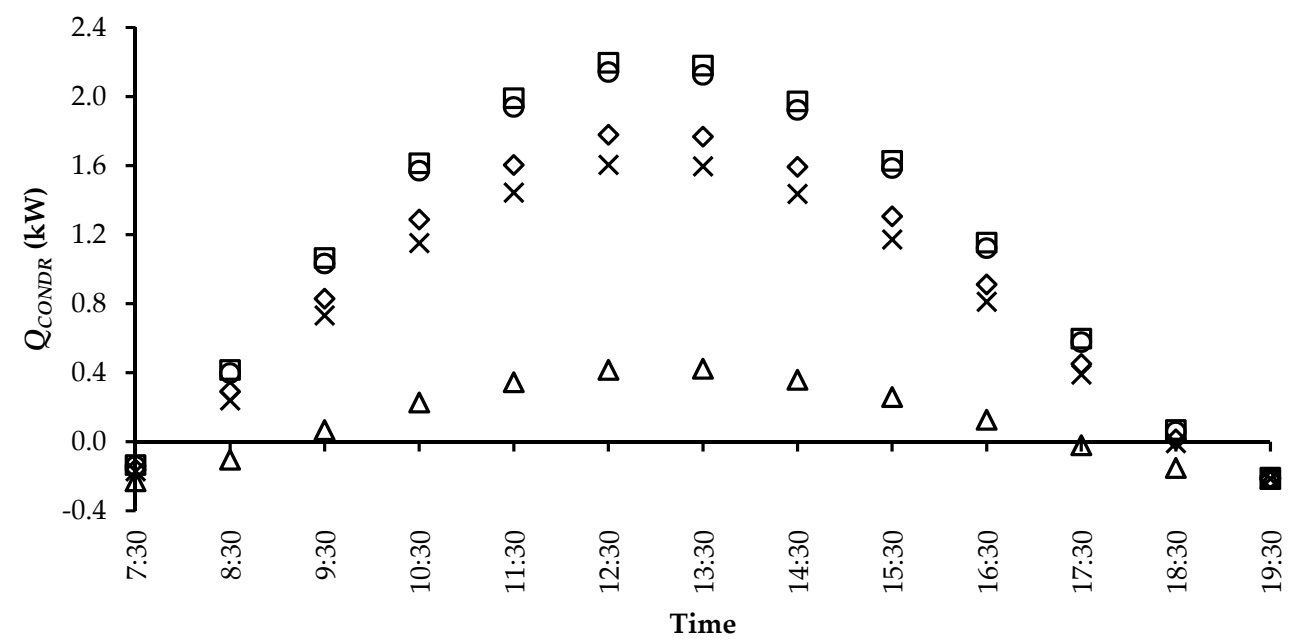

$\diamond$ Red (Baseline) $\square$ Black oBrown $\times$ Orange $\Delta$ White

Figure 14. Diurnal annual-averaged $Q_{C O N D R}$ profiles of BIMs for different roof tile colours.

Adoption of white roof tiles results in the lowest diurnal $Q_{C O N D R}$ values and conversely, adoption of dark colours, which are black and brown, results in the highest $Q_{C O N D R}$ values. Moreover, the adoption of vivid colours, which are red and orange, results in $Q_{C O N D R}$ values that are intermediary to those that resulted from the adoption of the white and dark colour groups. Values at troughs and peaks of the $Q_{C O N D R}$ profiles for each roof tile colour as well as the times when the values are obtained, in order of the impacts of each colour on decreasing the heat transfer, are enumerated in Table 2. Trough levels of the $Q_{C O N D R}$ profiles, which range between $-0.21 \mathrm{~kW}$ and $-0.23 \mathrm{~kW}$, are reached at 7:30 for white roof tiles and 19:30 for the other colours. On the other hand, in general, peak levels are reached at 12:30 and 13:30, with values that range between $0.42 \mathrm{~kW}$ that resulted from the adoption of white roof tiles and $2.19 \mathrm{~kW}$ that resulted from the adoption of black roof tiles.

Table 2. Values at troughs and peaks of diurnal $Q_{C O N D R}$ profiles for each roof tile colour and times when the values were obtained.

\begin{tabular}{|c|c|c|c|c|c|}
\hline \multirow{2}{*}{\multicolumn{2}{|c|}{ Roof Tile Colour }} & \multicolumn{2}{|c|}{ Trough } & \multicolumn{2}{|c|}{ Peak } \\
\hline & & Value (kW) & Time & Value $(\mathrm{kW})$ & Time \\
\hline \multicolumn{2}{|c|}{ White } & -0.23 & $7: 30$ & 0.42 & $12: 30$ and $13: 30$ \\
\hline \multirow{2}{*}{ Vivid } & Orange & -0.22 & $19: 30$ & 1.60 & $12: 30$ and $13: 30$ \\
\hline & Red (Baseline) & -0.21 & $19: 30$ & 1.78 & $12: 30$ \\
\hline \multirow{2}{*}{ Dark } & Brown & -0.21 & $19: 30$ & 2.14 & $12: 30$ \\
\hline & Black & -0.21 & $19: 30$ & 2.19 & $12: 30$ \\
\hline
\end{tabular}


Figure 15 shows the diurnal annual-averaged profiles of heat conduction transfer through the ceiling board, $Q_{C O N D C}$, which were generated by applying, on $Q_{C O N D C}$ data, the same methodology employed to generate Figure 14. Positive $Q_{C O N D C}$ values denote that the heat conduction transfer occurs from the attic space into the indoor space through the ceiling board, whereas inversely, negative $Q_{C O N D R}$ values denote that the heat conduction transfer occurs from the indoor space to the attic space.

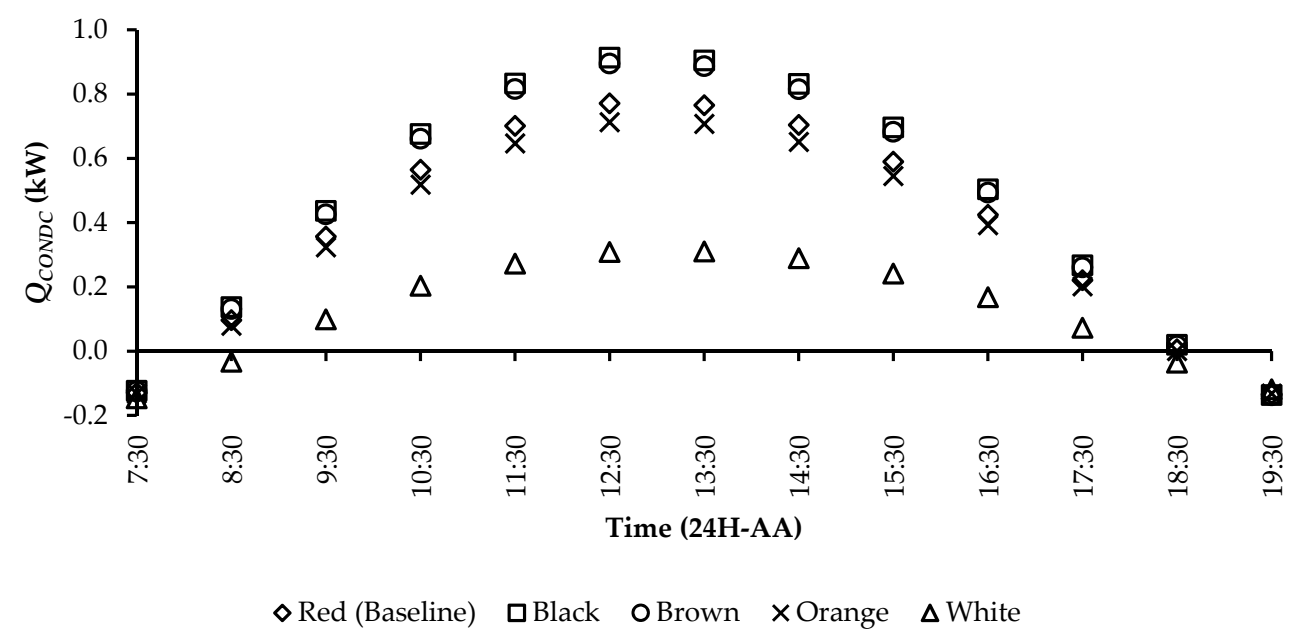

Figure 15. Diurnal annual-averaged $Q_{C O N D C}$ profiles of BIM for different roof tile colours.

Relative impacts of adopting different roof tile colours on the $Q_{C O N D C}$ profiles correspond to that of the $Q_{C O N D R}$ profiles, where the adoption of white, vivid and dark roof tiles generates the lowest, intermediary and highest $Q_{C O N D R}$ and $Q_{C O N D C}$ values, respectively. Table 3 accentuates the values at troughs and peaks of the $Q_{C O N D C}$ profiles for every roof tile colour plus the times when the trough and peak levels of heat transfer are reached, analogously to Table 2 .

Table 3. Values at troughs and peaks of diurnal $Q_{C O N D C}$ profiles for each roof tile colour and times when the values were obtained.

\begin{tabular}{cccccc}
\hline \multirow{2}{*}{ Roof Tile Colour } & \multicolumn{2}{c}{ Trough } & \multicolumn{2}{c}{ Peak } \\
\cline { 3 - 6 } & Value (kW) & Time & Value (kW) & Time \\
\hline \multirow{2}{*}{ White } & -0.15 & $7: 30$ & 0.31 & $12: 30$ and 13:30 \\
\hline \multirow{2}{*}{ Vivid } & Orange & -0.13 & $7: 30$ and 19:30 & 0.71 & $12: 30$ and 13:30 \\
& Red (Baseline) & -0.13 & $7: 30$ and 19:30 & 0.77 & $12: 30$ and 13:30 \\
\hline \multirow{2}{*}{ Dark } & Brown & -0.14 & $19: 30$ & 0.89 & $12: 30$ and 13:30 \\
& Black & -0.14 & $19: 30$ & 0.91 & $12: 30$ \\
\hline
\end{tabular}

Results indicate that selection of roof tile colours with high solar reflectance such as white and orange induces the highest reductions of heat conduction transfer owing to the reflection of higher amounts of heat from solar radiation at the surface of the roof tiles, which consequently impedes heat conduction transfer into the attic space and subsequently reduces heat conduction transfer through the ceiling board.

In contrast to the diurnal heat conduction transfer, Figures 16 and 17, which present nocturnal annual-averaged $Q_{C O N D R}$ and $Q_{C O N D C}$ profiles, respectively, reveal that the adoption of different roof tile colours has an insubstantial effect on the nocturnal heat transfer. The profiles are generated using data logged from 19:30 to 7:30 based on the same methodology adopted to produce Figures 14 and 15. 


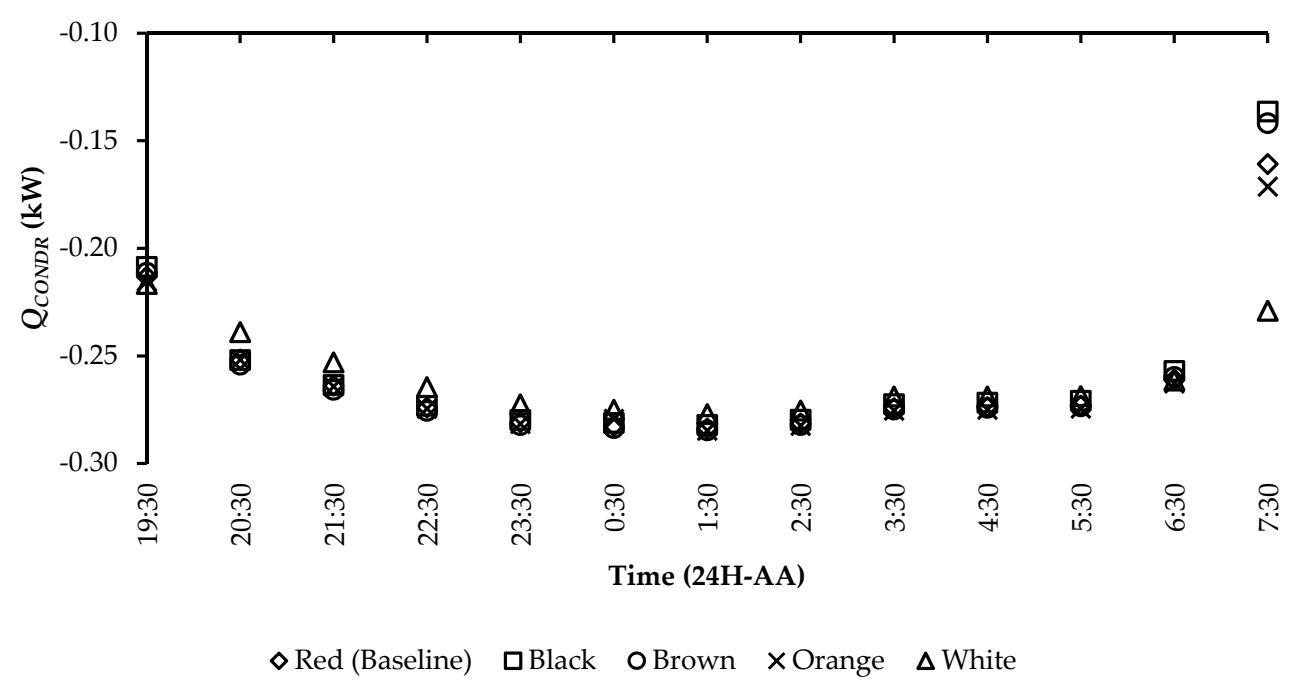

Figure 16. Nocturnal annual-averaged $Q_{C O N D R}$ profiles of BIM at different roof tile colours.

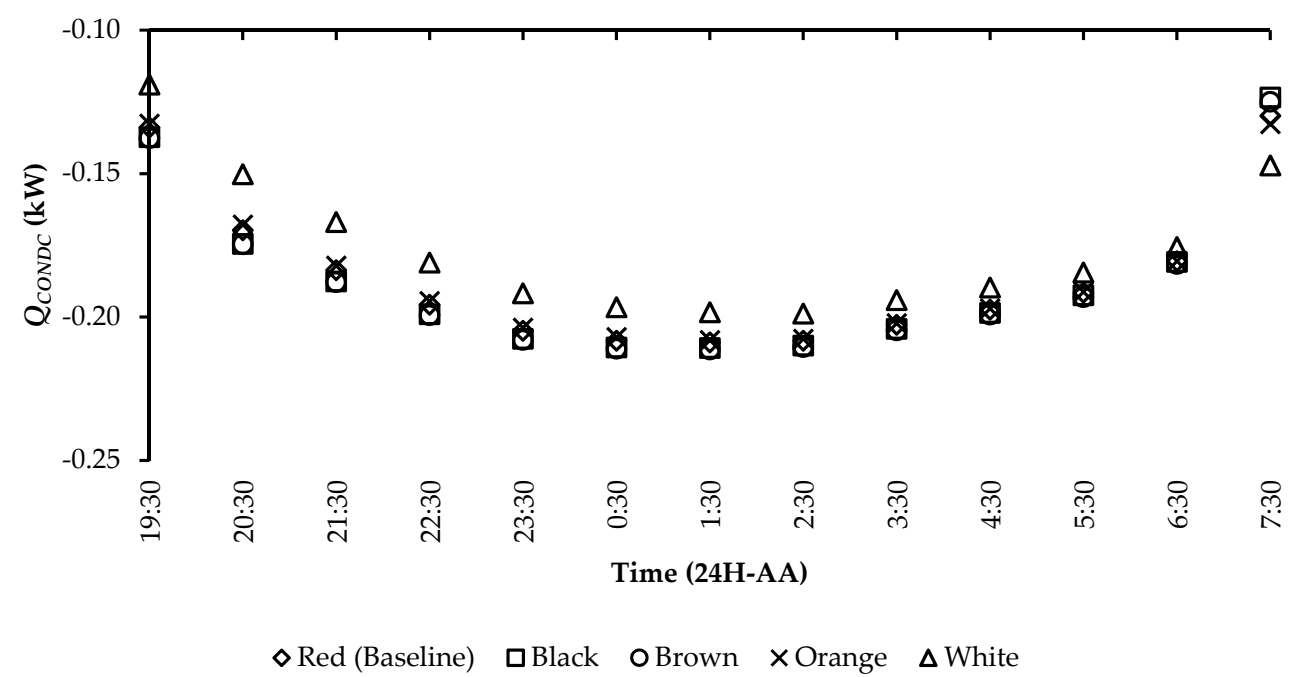

Figure 17. Nocturnal annual-averaged $Q_{C O N D C}$ profiles of BIM at different roof tile colours.

Diurnal $Q_{C O N D R}$ and $Q_{C O N D C}$ show positive values while the values of nocturnal $Q_{C O N D R}$ and $Q_{C O N D C}$ are negative, which suggest that the direction of heat conduction transfer changes as the conversion from day to night takes place. The change in direction of the heat conduction transfer is due to the absence of solar radiation at night that causes the average effective sky temperature to significantly reduce to $15^{\circ} \mathrm{C}$ and, as a consequence, the roof tiles release heat by radiation transfer to the night sky that acts as a heat sink, which subsequently induces heat conduction transfer from the indoor space to the roof tiles through the ceiling board and attic space to obtain thermal equilibrium [25]. Figures 18 and 19 present the diurnal and nocturnal annual-averaged profiles of the rooftop surface temperature, $T_{R S}$, for each roof tile colour, which evidently show trends that are similar to $Q_{C O N D R}$ and $Q_{C O N D C}$ as they are all heavily influenced by the trends of solar radiation and ambient temperature. It can be highlighted that, as indicated in Figure 18, diurnal peak $T_{R S}$ can reach as high as $54.98^{\circ} \mathrm{C}$ at 13:30 when black roof tiles are adopted and the peak can be reduced to as low as $35.84^{\circ} \mathrm{C}$ if the roof tile colour is changed to white, while, as revealed in Figure 19, nocturnal $T_{R S}$ can drop to as low as $21.87^{\circ} \mathrm{C}$ at 6:30. 


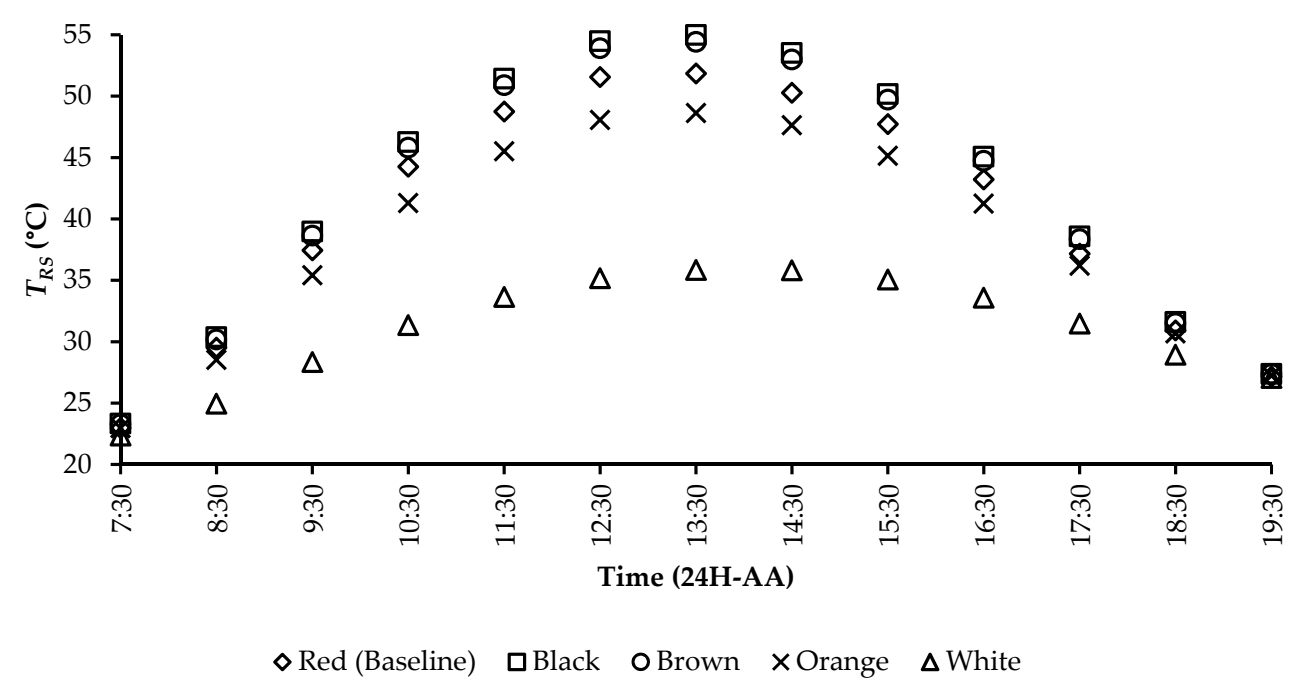

Figure 18. Diurnal annual-averaged $T_{R S}$ profiles at different roof tile colours.

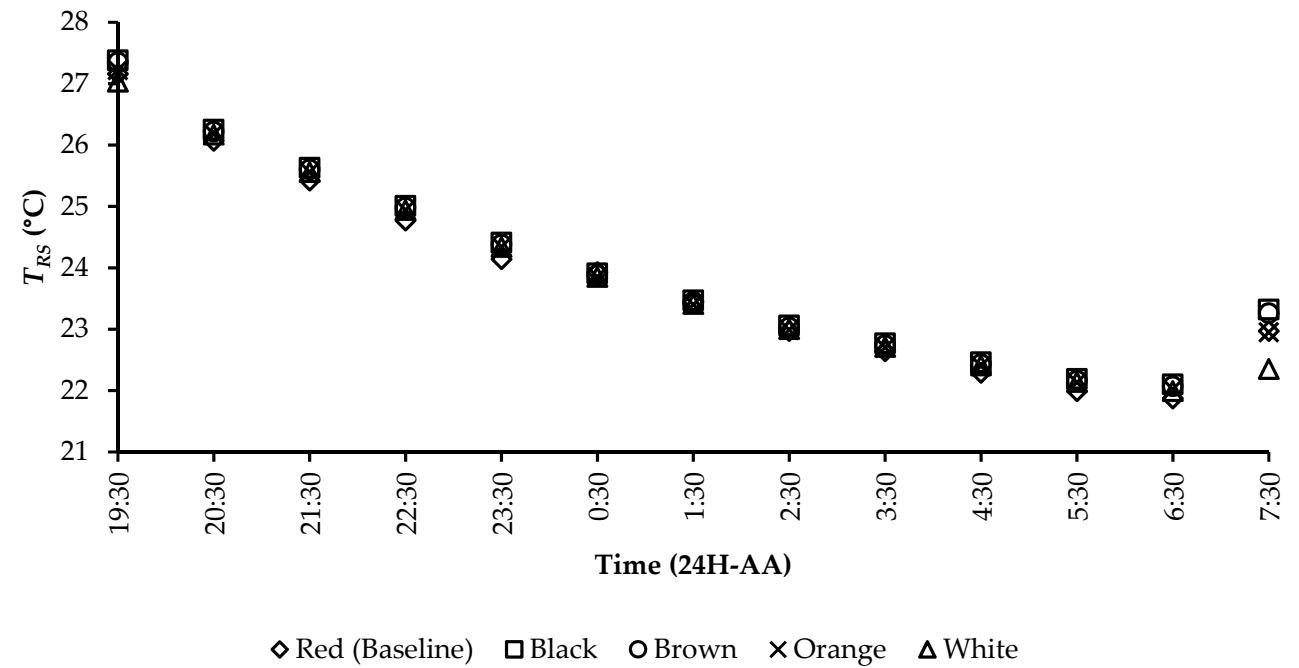

Figure 19. Nocturnal annual-averaged $T_{R S}$ profiles at different roof tile colours.

\section{Discussion}

Figure 20 highlights the peak heat conduction transfer, $Q_{C O N D P E A K}$, through the roof tiles and ceiling board for each roof tile colour based on the $Q_{C O N D R}$ and $Q_{C O N D C}$ profiles presented in Figures 14 and 15, respectively. $Q_{\text {CONDPEAK values through the roof tiles are }}$ higher than those through the ceiling board due to the more prolonged exposure of the roof tile surface directly to intense solar radiation in comparison to the ceiling board, which is shielded from the solar radiation by the roof tiles. Results indicate that the adoption of dark roof tile colours induces unfavourable increments to $Q_{\text {CONDPEAK values relative to }}$ the baseline BIM. Initial $Q_{C O N D P E A K}$ value through the roof tiles of $1.78 \mathrm{~kW}$ for the baseline BIM increased to $2.19 \mathrm{~kW}$ or $2.14 \mathrm{~kW}$ when the roof tile colour was changed from red to black or brown, respectively. Conversely, in relation to the baseline BIM, findings suggest that the adoption of vivid or light roof tile colours results in the auspicious lowering of

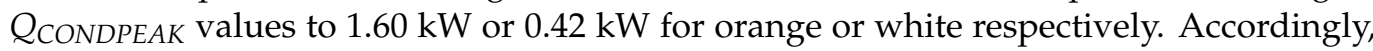
the initial $Q_{C O N D P E A K}$ value through the ceiling board of $0.77 \mathrm{~kW}$ for the baseline BIM increased to $0.91 \mathrm{~kW}$ or $0.89 \mathrm{~kW}$ when the roof tile colour was modified from red to black or brown, respectively, and decreased to $0.71 \mathrm{~kW}$ or $0.31 \mathrm{~kW}$ when orange or white were selected, respectively, in lieu of the aforementioned colours. 


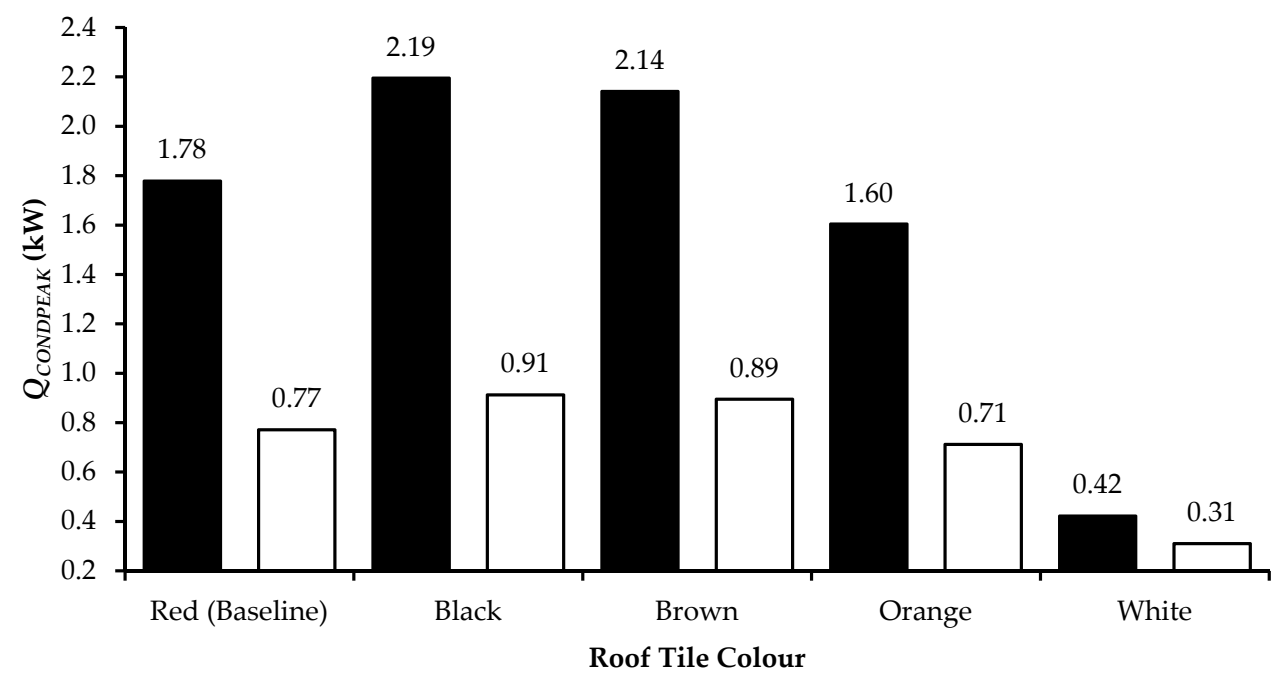

Doof Tiles $\square$ Ceiling Board

Figure 20. $Q_{C O N D P E A K}$ of BIM through roof tiles and ceiling board for different roof tile colours.

Figures 21 and 22 reveal the diurnal temperature gradient for roof-top surface, $\Delta T_{R S}$, of modified BIMs, relative to the baseline BIM. Figure 21 presents $\Delta T_{R S}$ values when lighter roof tile colours, which are orange and white, are adopted, whereas Figure 22 focuses on the darker roof tile colours, which are brown and black. According to Figure 21, the highest absolute values of $\Delta T_{R S}$ were obtained at $12: 30$, which are $-3.49^{\circ} \mathrm{C}$ and $-16.39^{\circ} \mathrm{C}$, when white and orange roof tiles were adopted, respectively. On the contrary, as presented in Figure 22, the highest absolute values of $\Delta T_{R S}$ of $2.70^{\circ} \mathrm{C}$ and $3.23^{\circ} \mathrm{C}$ were obtained at $14: 30$ when brown and black roof tiles were adopted, respectively.

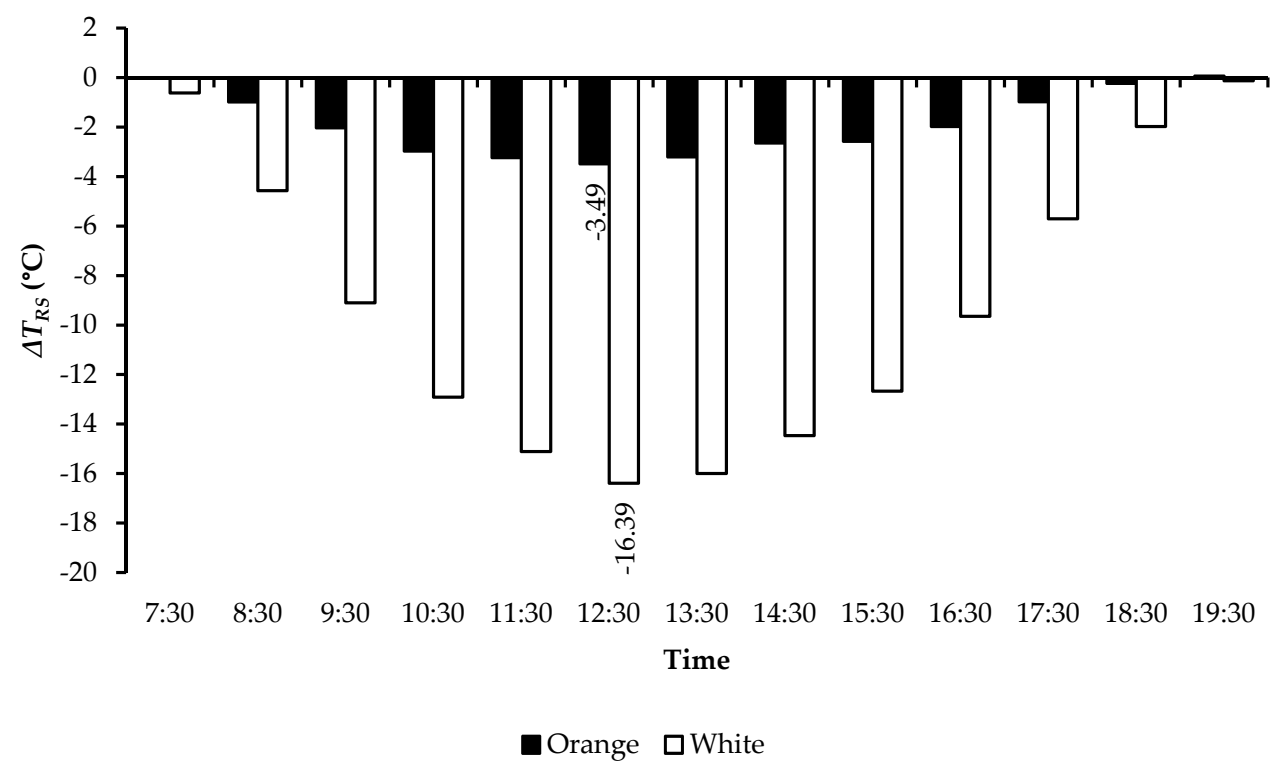

Figure 21. Diurnal $\Delta T_{R S}$ of modified BIM relative to the baseline BIM when lighter roof tile colours are adopted.

Figure 23 represents a plot of $T_{R S}$ against solar irradiation at different roof tile colours with linear trendlines depicted for the baseline BIM and the modified BIM that adopted white roof tiles. The plot reveals that when white roof tiles are adopted, the gradient of the linear trendline is greatly reduced from 0.0442 for the baseline BIM to 0.0169 for the modified BIM, hence indicating that white roof tiles are substantially effective at lowering 
the $T_{R S}$ when the roof tiles are subjected to prolonged and intense solar radiation, by virtue of their high solar reflectance that provides them with a relatively superior capability to reflect heat in comparison to other colours.

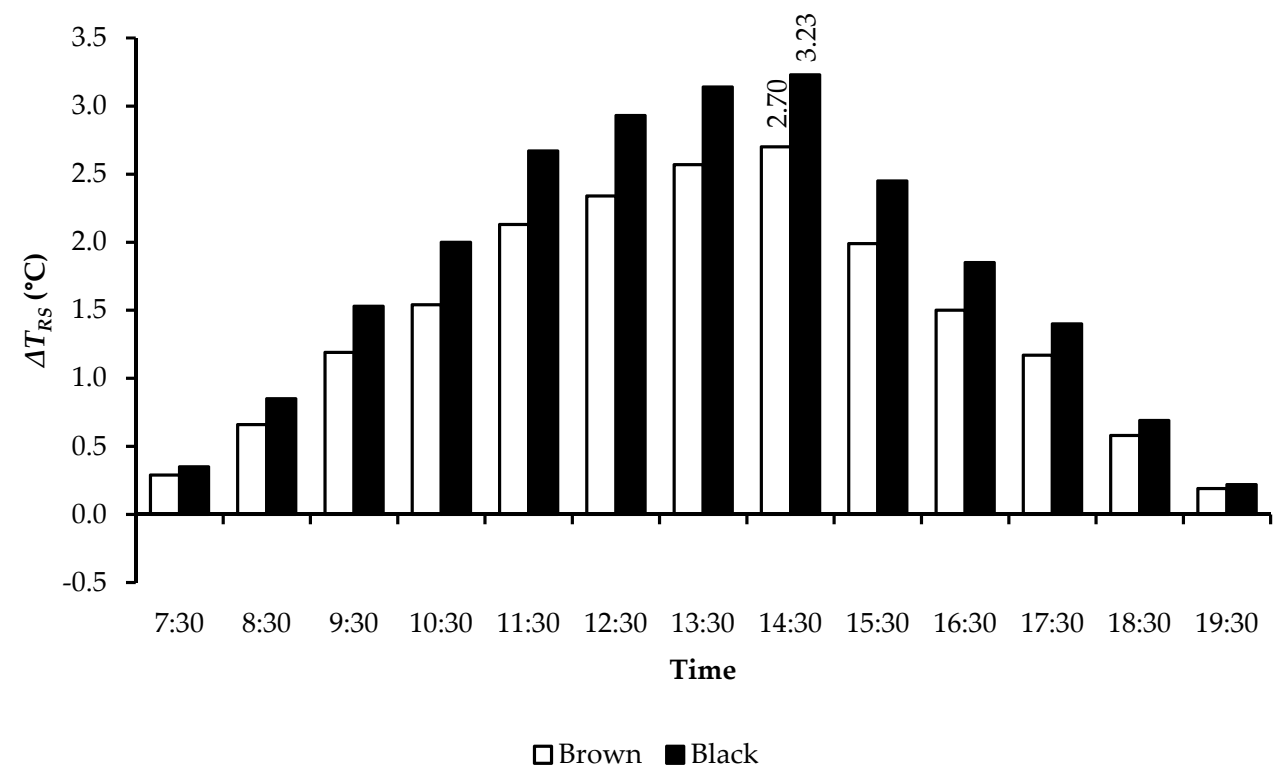

Figure 22. Diurnal $\Delta T_{R S}$ of modified BIM relative to the baseline BIM when darker roof tile colours are adopted.

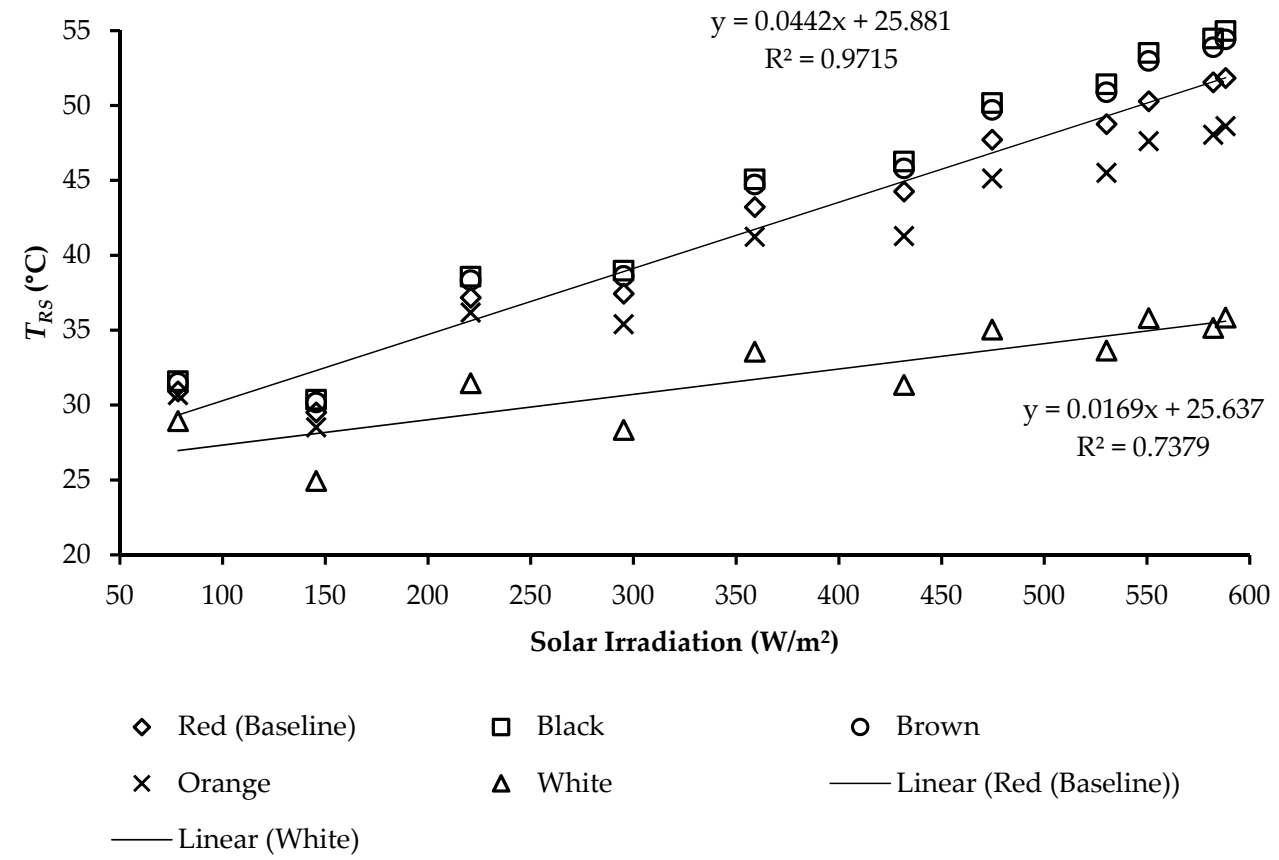

Figure 23. Plot of $T_{R S}$ against solar irradiation at different roof tile colours.

Figure 24 compares the peak roof-top surface temperatures, $T_{R S P E A K}$, with solar reflectance for different roof tile colours. In relation to the $T_{R S P E A K}$ value of $51.84{ }^{\circ} \mathrm{C}$ of the baseline BIM, which adopts red roof tiles with a solar reflectance of 0.2000 , adoption of black roof tiles with a low solar reflectance of 0.0450 results in the rise of $T_{R S P E A K}$ to $54.98^{\circ} \mathrm{C}$ when black roof tiles are adopted, whereas contrariwise, adoption of white roof tiles with a high solar reflectance of 0.7300 results in the curtailment of $T_{R S P E A K}$ at $35.84{ }^{\circ} \mathrm{C}$. 


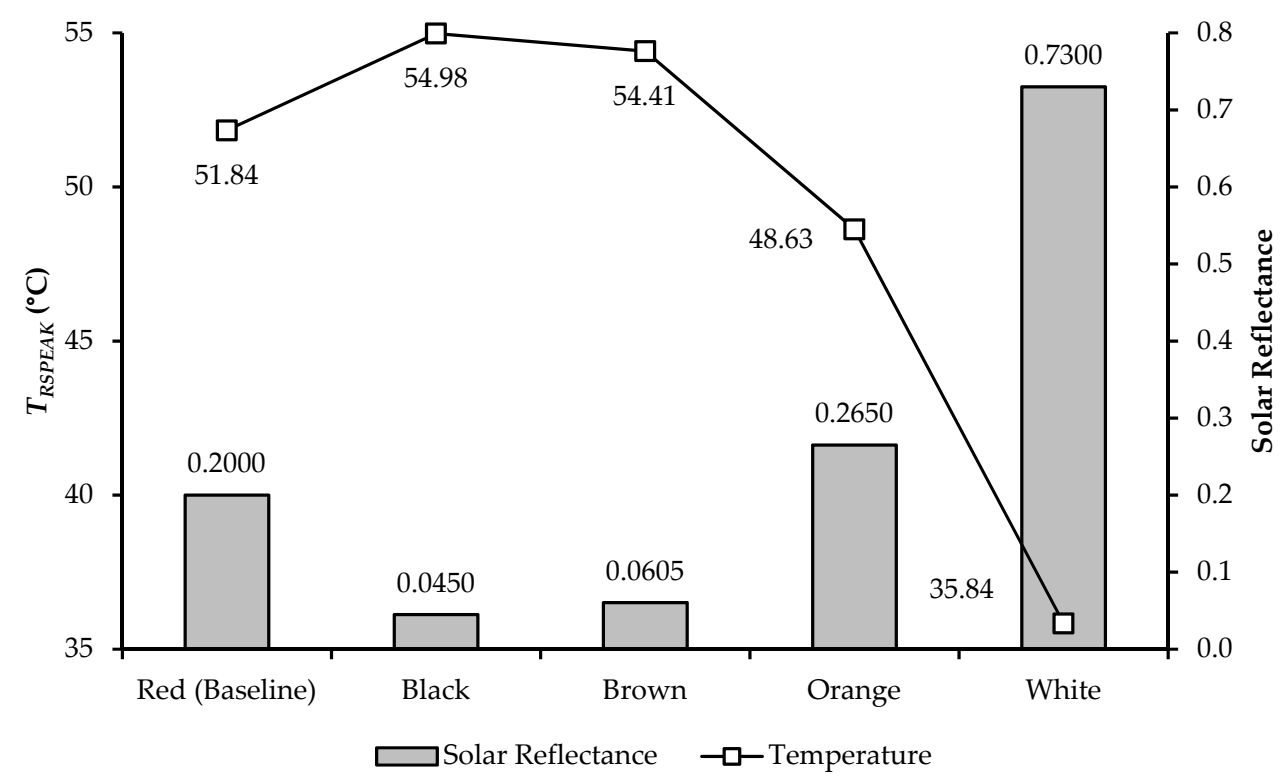

Figure 24. $T_{R S P E A K}$ and solar reflectance at different roof tile colours.

A plot of $T_{R S P E A K}$ against solar reflectance is presented in Figure 25, which highlights the effectiveness of increasing solar reflectance on lowering $T_{R S P E A K}$ and thus inhibiting the increase in $T_{R S}$ in the afternoon. In addition, the gradient of peak temperature for roof-top surface, $\triangle T_{R S P E A K}$, of the modified BIMs relative to the baseline BIM is highlighted in Figure 26, which reveals that, relative to the baseline BIM that adopts red roof tiles, the adoption of darker colours raises $T_{\text {RSPEAK }}$ by $2.57{ }^{\circ} \mathrm{C}$ and $3.14^{\circ} \mathrm{C}$ when brown and black roof tiles are adopted, respectively. Furthermore, the adoption of a more vivid colour, which is orange, decreases $T_{R S P E A K}$ by $3.21^{\circ} \mathrm{C}$ and compellingly, the adoption of white roof tiles results in a vast decline of $T_{R S P E A K}$ of $16.00{ }^{\circ} \mathrm{C}$, which is the highest absolute value $T_{\text {RSPEAK }}$ obtained from the simulation.

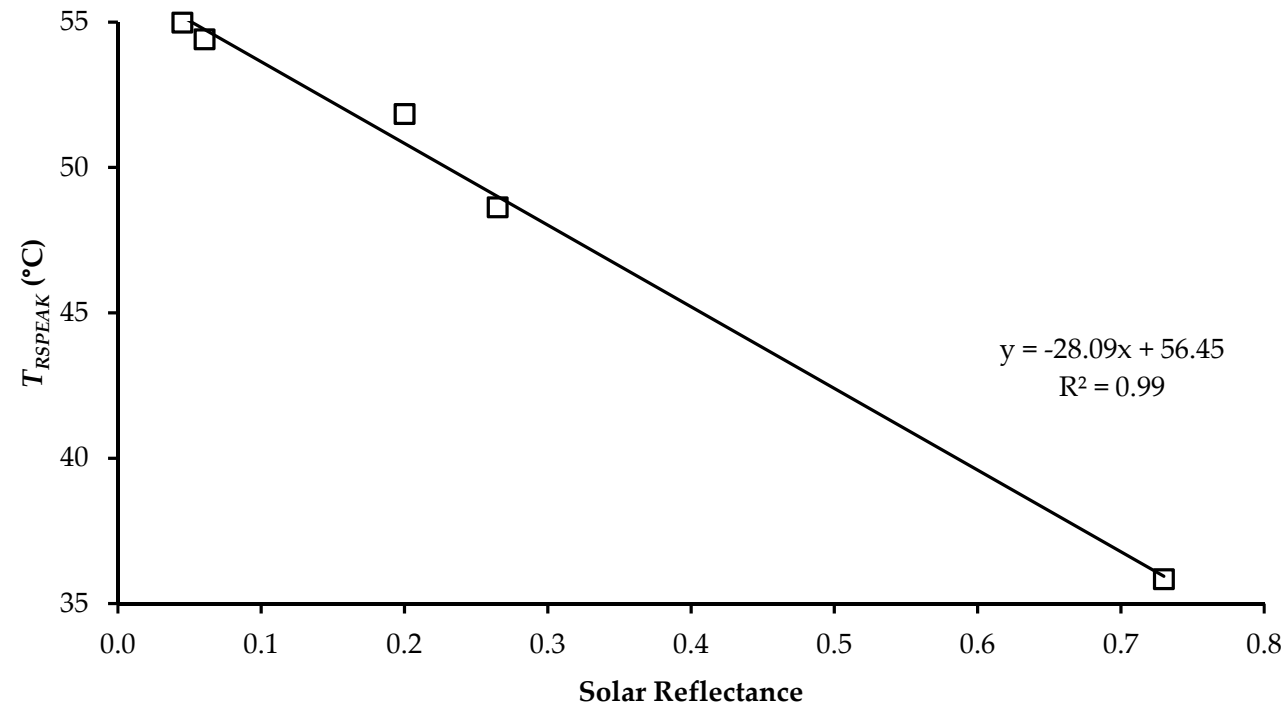

Figure 25. Plot of $T_{R S P E A K}$ against solar reflectance. 


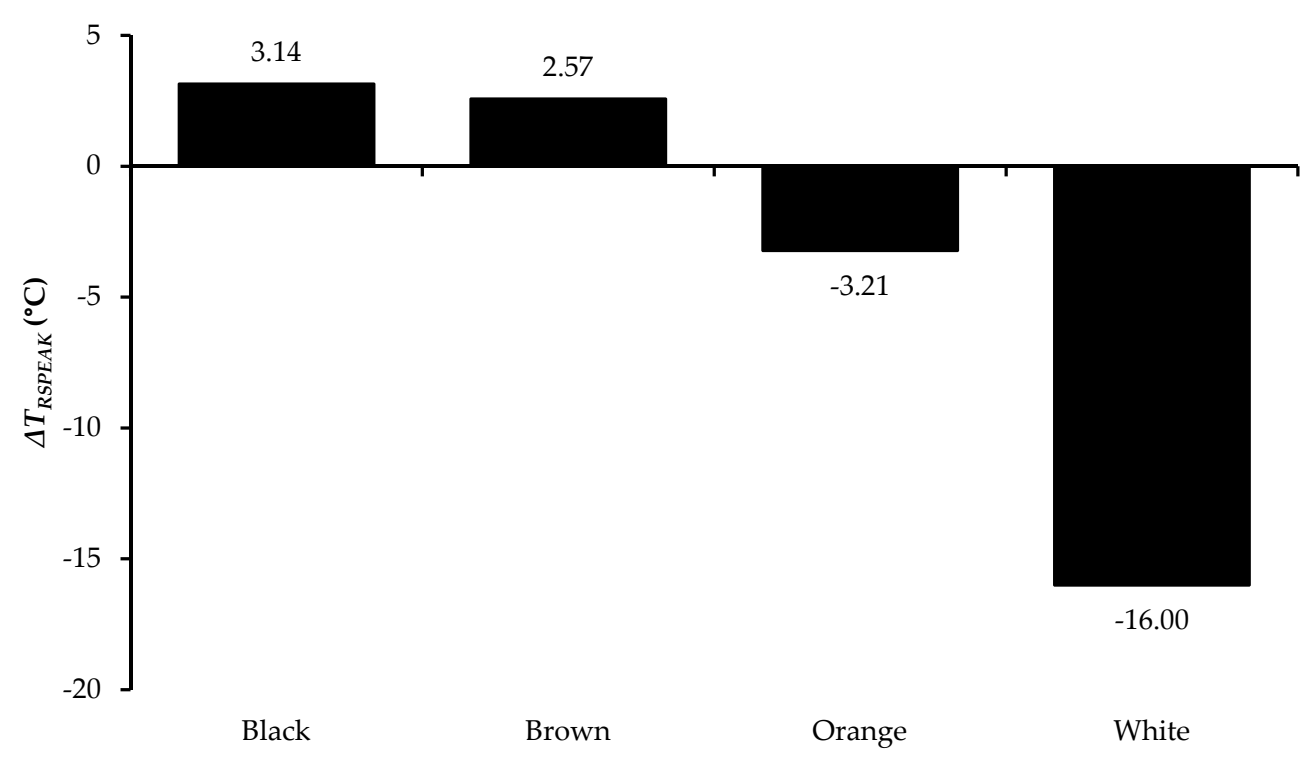

Figure 26. $\triangle T_{R S P E A K}$ of modified BIM relative to the baseline BIM.

Figure 27 plots cooling load against $T_{R S P E A K}$ and the plot indicates that the cooling load has a positive correlation with $T_{\text {RSPEAK }}$ and hence restraining the rise in $T_{\text {RSPEAK }}$ values is indispensable to the minimization of cooling load. Annual cooling load and energy savings of the indoor space of the BIM at different roof tile colours are revealed in Figure 28. Annual cooling load increases from 2.6671 MWh for the baseline BIM to 2.7695 MWh and 2.7592 MWh for the modified BIMs that adopt darker roof tile colours, which are black and brown respectively. Contrarily, annual cooling load decreases to 2.6242 MWh when orange, which is a more vivid colour, is adopted and drops further to $2.3166 \mathrm{MWh}$ when white, which is a lighter colour, is employed. In addition, annual energy savings of up to $13.14 \%$ can be achieved when the roof tile colour is changed from red, as adopted for the baseline BIM, to white. Hence, modification of roof tile colour to white is exhorted for occupants as it is a straightforward and cost-effective solution, albeit expedient, to reduce hours of indoor thermal discomfort and use of air-conditioners in indoor spaces.

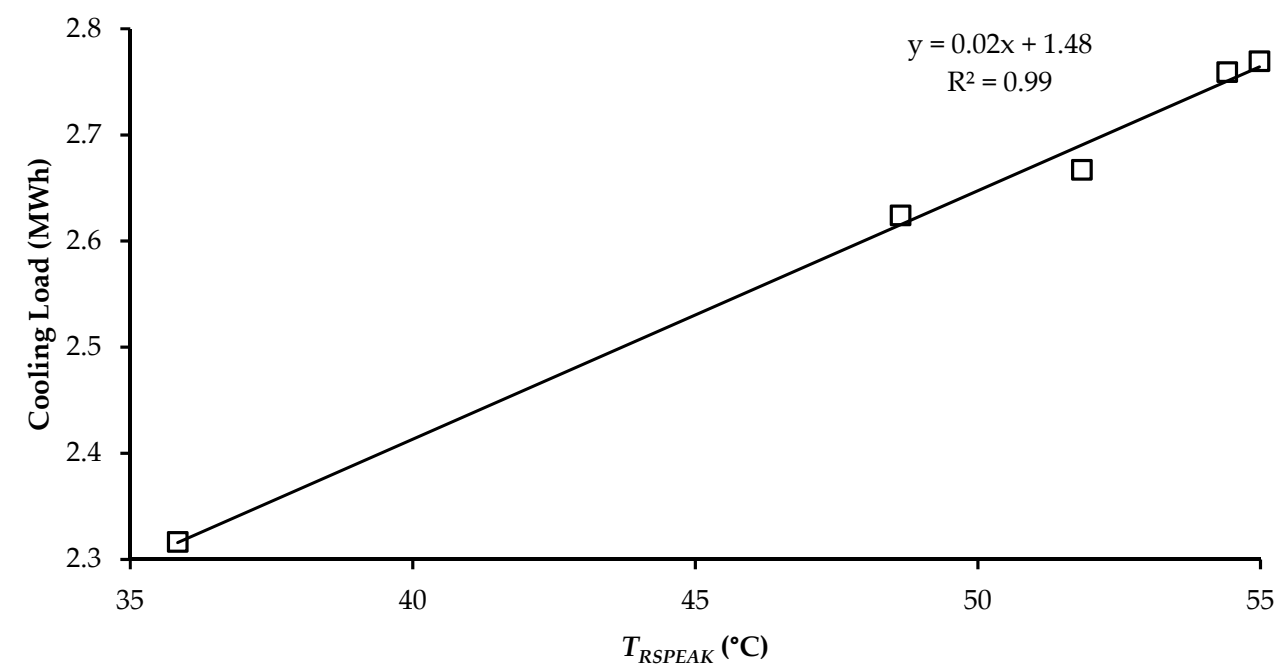

Figure 27. Plot of cooling load against $T_{\text {RSPEAK }}$. 


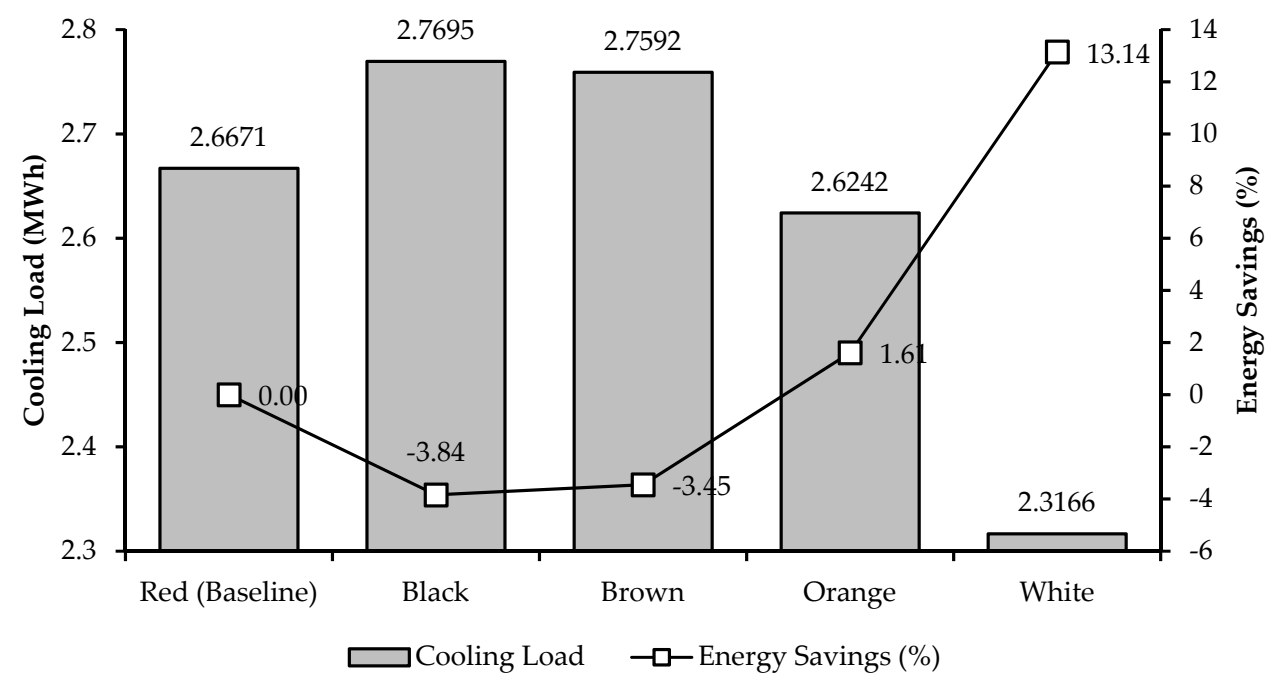

Figure 28. Annual cooling load and energy savings at different roof tile colours.

\section{Conclusions}

Findings on the effect of roof tile colour on heat conduction transfer through roof tiles and ceiling boards and roof-top surface temperature have been revealed and the impact of the roof-top surface temperature on annual cooling load and energy savings has been analyzed. The solar reflectance value of white roof tiles of 0.7300 is the highest among all of the other common roof tile colours and is significantly higher than the second and third highest solar reflectance values of 0.2650 for the red roof tiles, which is the most common roof tile colour of modern residential buildings in Malaysia, and 0.2000 for the orange roof tiles. On the other hand, infrared emittance values are high for all roof tile colours, which range between 0.880 and 0.915 . The selection of white roof tiles significantly reduces the diurnal peak of heat conduction transfer and temperature as well as the values of heat conduction transfer and temperature throughout the diurnal profiles as white roof tiles reflect a significantly higher amount of heat from solar radiation and consequently reduces heat conduction transfer through the roof tiles and into the attic space and subsequently through the ceiling board and into the indoor space. Contrary to the impact of roof tile colours on diurnal profiles, results reveal that it does not influence the nocturnal profiles as a release of heat to the sky takes place throughout the night. The release of heat from the building occurs due to the absence of solar radiation, which reduces the sky temperature and enables the sky to act as a heat sink that promotes the transfer of heat from the building to the sky to achieve thermal equilibrium.

Employing white roof tiles is highly recommended due to its significantly higher solar reflectance and impact on reducing heat conduction transfer and temperature, which consequently reduces hours of indoor thermal discomfort and use of air-conditioners in indoor spaces. The decline of peak roof-top surface temperature of up to $16.00{ }^{\circ} \mathrm{C}$ that results in annual energy savings of up to $13.14 \%$ can be achieved when the roof tile colour is changed from red to white. However, white roof tiles are not preferred by house buyers due to the high tendency of discolouration and maintenance difficulties as highlighted in Al Yacouby et al. [6]. Furthermore, Levinson et al. [38,39], Synnefa et al. [40] and Thongkanluang et al. [13] mentioned that house buyers generally do not prefer white colours due to aesthetic factors. Hence, further research on the development of solarreflective paint or coating products that can potentially increase the solar reflectance values of non-white roof tiles to values that are higher than 0.7000 is essential to overcome issues related to maintenance difficulties and lack of preference among house buyers towards white roof tiles. Concurrently, the adoption of white roof tiles or other non-white roof tile colours with high solar reflectance in countries subjected to tropical climates can be increased by spreading awareness among house owners, through various stakeholders, 
that emphasizes the cost savings that the house owners can enjoy, which can potentially, from the stance of the house owners, outweigh all of the other disadvantages.

Author Contributions: Conceptualization, S.A.F. and N.S.; methodology, S.A.F. and A.Z.-A.; validation, F.I.I.; formal analysis, S.A.F. and N.H.; investigation, F.I.I.; resources, O.K. and N.S.; data curation, F.I.I. and N.H.; writing-original draft, S.A.F. and F.I.I.; writing-review and editing, O.K. and A.I.A.H.; visualization, S.A.F. and A.I.A.H.; supervision, N.S. and A.Z.-A.; project administration, O.K. and N.S.; funding acquisition, O.K. and N.S. All authors have read and agreed to the published version of the manuscript.

Funding: The research received financial support from KDC Consultants, Bangladesh, via fund number 0153AB-M11 as administered by the Research Management Centre of Universiti Teknologi PETRONAS, Malaysia.

Institutional Review Board Statement: Not applicable.

Informed Consent Statement: Not applicable.

Data Availability Statement: The data presented in this study are available on request from the corresponding author.

Acknowledgments: The authors are thankful to the Institute of Science of Universiti Teknologi MARA Shah Alam, Malaysia as well as KDC Consultants, Bangladesh for the support and collaboration.

Conflicts of Interest: The authors declare no conflict of interest.

$\begin{array}{ll}\text { Nomenclature } \\ \text { Abbreviations } & \\ \text { BIM } & \text { Building Information Model } \\ \text { IES }<\text { VE }> & \text { Integrated Environmental Solutions <Virtual Environment> } \\ \text { TCA } & \text { Test Cell A } \\ \text { TCB } & \text { Test Cell B } \\ \text { Notations } & \\ A_{1} & \text { Area of the first surface } \\ d T / d x & \text { Temperature gradient } \\ \text { FM } & \text { Field measurements } \\ h_{r} & \text { Coefficient of heat transfer } \\ k & \text { Thermal conductivity } \\ P D_{S D-F M} & \text { Percentage difference between SD and FM } \\ Q_{C O N D C} & \text { Heat conduction transfer through ceiling board } \\ Q_{C O N D P E A K} & \text { Peak heat conduction transfer } \\ Q_{C O N D R} & \text { Heat conduction transfer through roof tiles } \\ Q_{\text {conduction }} & \text { Heat transfer by conduction } \\ Q_{\text {radiation }} & \text { Heat transfer by radiation } \\ \text { SD } & \text { Simulation data } \\ T_{P E A K} & \text { Peak temperature } \\ T_{R S} & \text { Roof-top surface temperature } \\ T_{R S P E A} & \text { Peak roof-top surface temperature } \\ T_{1} & \text { Absolute temperature of the first surface } \\ T_{2} & \text { Absolute temperature of the second surface } \\ \Delta T_{R S} & \text { Temperature gradient for roof-top surface } \\ \Delta T_{R S P A K} & \text { Gradient of peak temperature for roof-top surface } \\ \varepsilon_{1} & \text { Emissivity of the first surface } \\ \sigma & \text { Stefan-Boltzmann constant } \\ \end{array}$

\section{References}

1. Al-Obaidi, K.M.; Ismail, M.; Abdul Rahman, A.M. Passive cooling techniques through reflective and radiative roofs in tropical houses in Southeast Asia: A literature review. Front. Archit. Res. 2014, 3, 283-297. [CrossRef]

2. Alam, S.S.; Omar, N.A.; Ahmad, M.S.; Siddiquei, H.R.; Nor, S.M. Renewable energy in Malaysia: Strategies and development. Environ. Manag. Sustain. Dev. 2013, 2, 51-66. [CrossRef] 
3. Jayasinghe, M.T.R.; Attalage, R.A.; Jayawardena, A.I. Roof orientation, roofing materials and roof surface color: Their influence on indoor thermal comfort in warm humid climates. Energy Sustain. Dev. 2003, 7, 16-27. [CrossRef]

4. Department of Statistics, Malaysia. Population and Housing Census of Malaysia 2000: Household Characteristics; Department of Statistics, Malaysia: Putrajaya, Malaysia, 2004.

5. Department of Statistics, Malaysia. Population and Housing Census of Malaysia: Characteristics of Household; Department of Statistics, Malaysia: Putrajaya, Malaysia, 2010.

6. Al Yacouby, A.M.; Khamidi, M.F.; Nuruddin, M.F.; Farhan, S.A.; Razali, A.E. Study on roof tile's colors in Malaysia for development of new anti-warming roof tiles with higher Solar Reflectance Index (SRI). In Proceedings of the National Postgraduate Conference: Energy and Sustainability: Exploring the Innovative Minds (NPC 2011), Perak, Malaysia, 19-20 September 2011.

7. Kubota, T.; Jeong, S.; Toe, D.H.C.; Ossen, D.R. Energy consumption and air-conditioning usage in residential buildings of Malaysia. In Proceedings of the 11th International Conference on Sustainable Environmental Architecture (SENVAR 2010), Surabaya, Indonesia, 14-16 October 2010.

8. Miranville, F.; Boyer, H.; Mara, T.; Garde, F. On the thermal behaviour of roof-mounted radiant barriers under tropical and humid climatic conditions: Modelling and empirical validation. Energy Build. 2003, 35, 997-1008. [CrossRef]

9. Al-Obaidi, K.M.; Ismail, M.; Abdul Rahman, A.M. Investigation of passive design techniques for pitched roof systems in the tropical region. Mod. Appl. Sci. 2014, 8, 182-191. [CrossRef]

10. Lee, S.W.; Lim, C.H.; Chan, S.A.; Von, K.L. Techno-economic evaluation of roof thermal insulation for a hypermarket in equatorial climate: Malaysia. Sustain. Cities Soc. 2017, 35, 209-223. [CrossRef]

11. Vijaykumar, K.C.K.; Srinivasan, P.S.S.; Dhandapani, S. A performance of hollow tiles clay (HTC) laid reinforced cement concrete (RCC) roof for tropical summer climates. Energy Build. 2007, 39, 886-892. [CrossRef]

12. Patterson, S.; Mehta, M. Roofing Design and Practice; Prentice-Hall, Inc.: Hoboken, NJ, USA, 2001.

13. Thongkanluang, T.; Chirakanphaisarn, N.; Limsuwan, P. Preparation of NIR reflective brown pigment. Procedia Eng. 2012, 32, 895-901. [CrossRef]

14. Synnefa, A.; Santamouris, M.; Akbari, H. Estimating the effect of using cool coatings on energy loads and thermal comfort in residential buildings in various climatic conditions. Energy Build. 2007, 39, 1167-1174. [CrossRef]

15. Zingre, K.T.; Wan, M.P.; Wong, S.K.; Toh, W.B.T.; Lee, I.Y.L. Modelling of cool roof performance for double-skin roofs in tropical climate. Energy 2015, 82, 813-826. [CrossRef]

16. Syuhada, A.; Maulana, M.I. Heat transfer capability of solar radiation in colored roof and influence on room thermal comfort. AIP Conf. Proc. 2018, 1931, 030054. [CrossRef]

17. Jamaludin, N.; Mohammed, N.I.; Khamidi, M.F.; Abdul Wahab, S.N. Thermal comfort of residential building in Malaysia at different micro-climates. Procedia Soc. Behav. Sci. 2015, 170, 613-623. [CrossRef]

18. Puad, N.H.A.; Nuruddin, M.F.; Lian, J.J.; Othman, I. Roof insulation material from low density polyethylene (LDPE), kapok fibre and silica aerogel. In Engineering Challenges for Sustainable Future, Proceedings of the 3rd International Conference on Civil, Offshore and Environmental Engineering (ICCOEE 2016), Kuala Lumpur, Malaysia, 15-17 August 2016; Wan Abdullah Zawawi, N.A., Ed.; CRC Press/Balkema: Singapore, 2016; pp. 537-542.

19. Nuruddin, M.F.; Puad, N.H.A.; Zaidi, N.H.A. Effectiveness of aerogel roofing system on temperature reduction in Malaysian residential buildings. J. Eng. Appl. Sci. 2017, 12, 4057-4062. [CrossRef]

20. Amir, A.; Mohamed, M.F.; Mat Sulaiman, M.K.A.; Yusoff, W.F.M. Comparative assessment of passive design strategies for improving indoor thermal comfort of low-cost house in hot-humid climate of Malaysia. Int. J. Civ. Eng. Technol. 2018, 9, 1500-1514.

21. Amir, A.; Mohamed, M.F.; Mat Sulaiman, M.K.A.; Mohammad Yusoff, W.F. Assessment of indoor thermal condition of a low-cost single story detached house: A case study in Malaysia. Alam Cipta 2019, 12, 80-88.

22. UBBL 1984. Uniform Building By-Laws 1984. G.N. 5178/85. 2013.

23. Casini, M. Smart Buildings: Advanced Materials and Nanotechnology to Improve Energy-Efficiency and Environmental Performance; Woodhead Publishing: Cambridge, UK, 2016. [CrossRef]

24. Pisello, A.L. High-albedo roof coatings for reducing building cooling needs. In Eco-Efficient Materials for Mitigating Building Cooling Needs: Design, Properties and Applications; Pacheco-Torgal, F., Labrincha, J.A., Cabeza, L.F., Granqvist, C.-G., Eds.; Woodhead Publishing: Cambridge, UK, 2015; pp. 243-268. [CrossRef]

25. Tang, C.K.; Chin, N. Building Energy Efficiency Technical Guideline for Passive Design; Building Sector Energy Efficiency Project (BSEEP): Kuala Lumpur, Malaysia, 2013.

26. Howell, J.R.; Siegel, R.; Mengüç, M.P. Thermal Radiation Heat Transfer; CRC Press: Boca Raton, FL, USA, 2011.

27. Jayamaha, L. Energy Efficient Building Systems: Green Strategies for Operation and Maintenance; McGraw-Hill: New York, NY, USA, 2006.

28. Irwan, S.S.; Ahmed, A.Z.; Ibrahim, N.; Zakaria, N.Z. Roof angle for optimum thermal and energy performance of insulated roof. In Proceedings of the 3rd International Conference on Energy and Environment (ICEE2009), Malacca, Malaysia, 7-8 December 2009; pp. 145-150. [CrossRef]

29. Irwan, S.S.; Ahmed, A.Z.; Zakaria, N.Z.; Ibrahim, N. Thermal and energy performance of conditioned building due to insulated sloped roof. AIP Conf. Proc. 2010, 1250, 476. [CrossRef] 
30. Halim, N.H.A.; Ahmed, A.Z.; Zakaria, N.Z. Thermal and energy analysis of ceiling and pitch insulation for buildings in Malaysia. In Proceedings of the 3rd International Symposium and Exhibition in Sustainable Energy and Environment (ISESEE 2011), Malacca, Malaysia, 1-3 June 2011; pp. 214-220. [CrossRef]

31. Morris, F.; Ahmed, A.Z.; Zakaria, N.Z. Thermal performance of naturally ventilated test building with pitch and ceiling insulation. In Proceedings of the 3rd International Symposium and Exhibition in Sustainable Energy and Environment (ISESEE 2011), Malacca, Malaysia, 1-3 June 2011; pp. 221-226. [CrossRef]

32. Morris, F.; Zakaria, N.Z.; Ahmed, A.Z. Heat flux through naturally ventilated building in Malaysian climate. Appl. Mech. Mater. 2012, 204-208, 4384-4388. [CrossRef]

33. Zakaria, N.Z.; Ahmed, A.Z.; Ariffin, N.N.; Halim, N.H.A.; Morris, F. Thermal energy evaluation of building with ceiling insulation in warm-humid tropical climate. In Proceedings of 2011 IEEE Colloquium on Humanities, Science and Engineering (CHUSER 2011), Penang, Malaysia, 5-6 December 2011; pp. 233-238. [CrossRef]

34. Department of Statistics, Malaysia. Characteristics of Living Quarters 2010; Department of Statistics, Malaysia: Putrajaya, Malaysia, 2012.

35. Vangimalla, P.R.; Olbina, S.J.; Issa, R.R.; Hinze, J. Validation of Autodesk Ecotect ${ }^{\mathrm{TM}}$ accuracy for thermal and daylighting simulations. In Proceedings of the Winter Simulation Conference, Phoenix, AZ, USA, 11-14 December 2011; pp. 3383-3394. [CrossRef]

36. Leng, P.C.; Ahmad, M.H.; Osses, D.R.; Hamid, M. Investigation of Integrated Environmental Solutions-Virtual Environment software accuracy for air temperature and relative humidity of the test room simulations. In Proceedings of the Universiti Malaysia Terengganu 11th International Annual Symposium on Sustainability Science and Management, Terengganu, Malaysia, 9-11 July 2012; pp. 1298-1305.

37. Maamari, F.; Andersen, M.; de Boer, J.; Carroll, W.L.; Dumortier, D.; Greenup, P. Experimental validation of simulation methods for bi-directional transmission properties at the daylighting performance level. Energy Build. 2006, 38, 878-889. [CrossRef]

38. Levinson, R.; Akbari, H.; Reilly, J.C. Cooler tile-roofed buildings with near-infrared-reflective non-white coatings. Build Environ. 2007, 42, 2591-2605. [CrossRef]

39. Levinson, R.; Berdahl, P.; Akbari, H.; Miller, W.; Joedicke, I.; Reilly, J.; Suzuki, Y.; Vondran, M. Methods of creating solar-reflective nonwhite surfaces and their application to residential roofing materials. Sol. Energy Mater Sol. Cells 2007, 91, 304-314. [CrossRef]

40. Synnefa, A.; Santamouris, M.; Apostolakis, K. On the development, optical properties and thermal performance of cool colored coatings for the urban environment. Sol. Energy 2007, 81, 488-497. [CrossRef] 